BEHAVIORAL RESPONSES TO TAXES:

LESSONS FROM THE EITC AND LABOR SUPPLY

\author{
Nada Eissa
}

Hilary Hoynes

Working Paper 11729 
NBER WORKING PAPER SERIES

\title{
BEHAVIORAL RESPONSES TO TAXES: LESSONS FROM THE EITC AND LABOR SUPPLY
}

\author{
Nada Eissa \\ Hilary Hoynes \\ Working Paper 11729 \\ http://www.nber.org/papers/w11729 \\ NATIONAL BUREAU OF ECONOMIC RESEARCH \\ 1050 Massachusetts Avenue \\ Cambridge, MA 02138 \\ November 2005
}

This paper was prepared for the "Tax Policy and the Economy" conference held on September 15, 2005 in Washington DC. We wish to thank Jim Poterba for very useful comments; Bruce Meyer and Jesse Rothstein for providing us with data; Dan Feenberg for special tabulations from TAXSIM, and Jeff Rohaly of the Urban Institute for tabulations of SOI data; and Alan Barreca for research assistance. Correspondence to Hoynes at UC Davis, Department of Economics, 1152 Social Sciences and Humanities Building, One Shields Avenue, Davis, CA 95616-8578, phone (530) 752-3226, fax (530) 752-9382, hwhoynes@ucdavis.edu; or to Eissa at noe@georgetown.edu. The views expressed herein are those of the author(s) and do not necessarily reflect the views of the National Bureau of Economic Research.

(O2005 by Nada Eissa and Hilary Hoynes. All rights reserved. Short sections of text, not to exceed two paragraphs, may be quoted without explicit permission provided that full credit, including $\odot$ notice, is given to the source. 
Behavioral Responses to Taxes: Lessons from the EITC and Labor Supply

Nada Eissa and Hilary Hoynes

NBER Working Paper No. 11729

November 2005

JEL No. H24, J22

\begin{abstract}
Twenty-two million families currently receive a total of $\$ 34$ billion dollars in benefits from the Earned Income Tax Credit (EITC). In fact, the EITC is the largest cash transfer program for lowerincome families at the federal level. An unusual feature of the credit is its explicit goal to use the tax system to encourage and support those who choose to work. A large body of work has evaluated the labor supply effects the EITC and has generated several important findings regarding the behavioral response to taxes. Perhaps the main lesson learned from the evidence is the confirmation that real responses to taxes are important; labor supply does respond to the EITC. The second major lesson is related to the nature of the labor supply response. A consistent finding is that labor supply responses are concentrated along the extensive (entry) margin, rather than the intensive (hours worked) margin. This distinction has important implications for the design of tax-transfer programs and for the welfare evaluation of tax reforms.

Nada Eissa

The Car Barn, 418

Georgetown University

Washington, DC 20007

and NBER

noe@georgetown.edu

Hilary Hoynes

Department of Economics

University of California, Davis

One Shields Ave.

Davis, CA 95616-8578

and NBER

hwhoynes@ucdavis.edu
\end{abstract}




\section{Introduction and Overview}

The past two decades in the United States have witnessed an increasing reliance on the tax system as a means of providing cash assistance to lower-income families with children. A series of tax acts starting with the 1986 Tax Reform Act have increased assistance to the working poor through expansions of the Earned Income Tax Credit (EITC), making it the largest federal cash-transfer program for lower-income families with children. Over 20 million families are projected to have benefited from the tax credit in 2003, at a total cost to the federal government of more than 34 billion dollars ${ }^{1}$. These transfers have been especially successful at reducing poverty in the United States. In fact, Census data suggest that the federal credit now lifts more children out of poverty than any other government program. "Some 4.9 million people, including 2.7 million children, were removed from poverty in 2002 as a result of the federal EITC"(Llobrera and Zahradnik 2004). These estimates are consistent with the fact that the 1993 credit expansion was designed such that a full-time worker earning the minimum wage would not live in poverty.

This shift in the structure of public assistance is the outcome of a long-standing criticism that traditional welfare programs generate adverse incentives for work and family. Advocates of the Earned Income Tax Credit have argued that the credit helps "promote both the values of family and work." Indeed, economic theory suggests that the EITC should be especially successful at promoting entry in to the labor force among eligible, single taxpayers.

The recent expansions have offered researchers an excellent opportunity to evaluate the impacts of the EITC on behavior. Hotz and Scholz's (2003) review of the literature on the EITC shows that researchers have taken full advantage of this opportunity, examining outcomes such as work behavior, marriage, fertility, consumption expenditures and overall family well-being. Here, we concentrate on the impacts of the EITC on labor supply, and in particular on the lessons learned about the labor supply responses to tax-transfer programs. We argue that the evaluation of the EITC has been especially useful for the understanding the size and the composition of labor supply responses to tax incentives, and has informed the literature on the welfare evaluation of tax reforms as well as the optimal design of taxtransfer schemes.

In this review, we first provide a brief history of the EITC, along with a description of the current policies and recent tax expansions. In Section III, we provide a descriptive analysis of the EITC population. In particular, we use IRS data to examine the characteristics of EITC recipients including

\footnotetext{
${ }^{1}$ By comparison, federal spending on Temporary Assistance to Needy Families (TANF), which block grants Aid to Families with Dependent Children (AFDC), stands at about 18.6 billion dollars (Hotz and Scholz 2003).
} 
number of children, filing status and income. In Section IV, we use economic theory to discuss the expected impact of the EITC on labor supply. In short, among eligible unmarried women with children, the EITC is expected to increase employment but reduce hours of work for those already in the labor market. To target benefits to lower-income families, however, the EITC is based on family income, leading to a very different set of incentives for married taxpayers. Among secondary earners in married couples, the EITC is expected to reduce labor force participation and hours worked for those already in the labor force

Section V summarizes what is known about the impacts of the EITC on labor supply. The nature of the expected labor supply effects of the EITC lead us to structure our summary in the following manner. First, we examine the impacts on single and married taxpayers separately, focusing exclusively on women. ${ }^{2}$ Second, we examine separately the two different margins of labor supply responses- the extensive (employment) and intensive (hours worked by working individuals) margins. The overwhelming finding of the empirical literature is that EITC has been especially successful at encouraging the employment of single parents, especially mothers. There is little evidence, however, that the EITC has reduced the hours worked by those already in the labor force. The empirical literature on married women is somewhat smaller but again consistent in its findings. The studies show that the EITC leads to modest reductions in the employment and hours worked of married women.

In Section VI, we discuss the possible explanations for the empirical finding that the EITC affects the extensive but not the intensive margin. We also discuss the general equilibrium implications of the EITC - in particular whether the EITC affects gross wages. Finally, we discuss the implications of this work for the optimal design of the EITC. Recent work has emphasized the role of the extensive margin in the design of the tax-transfer schemes (Saez 2002) and the welfare evaluation of tax reform (Eissa, Kleven and Kreiner 2005). We first review this work and then discuss whether there are potential efficiency gains associated with modifying the EITC. Section VII presents our conclusions.

\section{Operation and Brief History of the EITC}

The Earned Income Tax Credit began in 1975 as a modest program aimed at offsetting the social security payroll tax for low-income families with children. It was the outcome of a vigorous policy debate surrounding the efficacy of a Negative Income Tax (NIT) as a means of reducing poverty. The concern was that the NIT-which guarantees a minimum standard of living to everyone-would discourage labor

\footnotetext{
${ }^{2}$ Our analysis of married couples focuses on married women because they have been found to be considerably more responsive to changes in wages and income than married men.
} 
market activity as it is gradually phased out. Ultimately the EITC was born out of a desire to reward work.

The EITC is refundable so that a taxpayer with no federal tax liability, for example, would receive a tax refund from the government for the full amount of the credit. Taxpayers may also receive the credit throughout the year with their paychecks; but in 2000, less than 5 percent of EITC recipients availed themselves of this early payment option (Friedman 2000). A taxpayer's eligibility for the earned income tax credit depends on the taxpayer's earned income (or in some cases adjusted gross income), and the number of qualifying children who meet certain age, relationship and residency tests. First, the taxpayer must have positive earned income, defined as wage and salary income, business self-employment income, and farm self-employment income. Also, the taxpayer must have adjusted gross income and earned income below a specified amount (in 2004, the maximum allowable income for a taxpayer with two or more children is $\$ 34,458$ ). Second, a taxpayer must have a qualifying child, who must be under age 19 (or 24 if a full-time student) or permanently disabled and residing with the taxpayer for more than half the year. ${ }^{3}$ Until 1991, the rules for EITC eligibility were more complicated and depended on the taxpayer's filing status ${ }^{4}$.

The amount of the credit to which a taxpayer is entitled depends on the taxpayer's earned income, adjusted gross income, and, since 1991, the number of EITC-eligible children in the household. There are three regions in the credit schedule. The initial phase-in region transfers an amount equal to the subsidy rate times their earnings. In tax year 2004, the subsidy rate of the EITC is 34 percent for taxpayers with one child and 40 percent for taxpayers with two or more children. In the flat region, the family receives the maximum credit ( $\$ 2604$ and $\$ 4300$, respectively), while in the phase-out region, the credit is phased out at the phase-out rate (16 and 21 percent).

Table I summarizes the parameters of the EITC over the history of the program. The program grew slowly from its introduction in 1975 until 1986, and in fact shrank in real terms due to inflation. The 1987 expansion of the EITC, passed as part of the Tax Reform Act of 1986 (TRA86), increased the generosity of the credit for the lowest-income workers and extended its benefits beyond the poorest (see Eissa and Liebman 1996) $)^{5}$. By 1988, taxpayers with incomes between $\$ 11,000$ and $\$ 18,576$ became eligible for the credit and faced its phase-out marginal tax rate for the first time. The 1987 EITC

\footnotetext{
${ }^{3}$ Beginning in 1994, a small credit is available to low-income workers without children.

${ }^{4}$ See Eissa and Liebman (1996) for a more extensive discussion of EITC rules.

${ }^{5}$ TRA86 returned the real maximum credit to its 1975 level, and indexed the EITC for inflation.
} 
expansion interacted with other tax changes implemented after TRA86-including greater personal exemption and standard deduction-to help eliminate taxes on poor families. The largest single expansion over this period was contained in the Omnibus Reconciliation Act of 1993 (OBRA93) legislation. The 1993 expansion of the EITC, phased in between 1994 and 1996, led to an increase in the subsidy rate from 19.5 percent to 40 percent (18.5 to 34 percent) and an increase in the maximum credit from $\$ 1,511$ to $\$ 3,556$ ( $\$ 1,434$ to $\$ 2,152$ ) for taxpayers with two or more children (taxpayers with one child). This expansion was substantially larger for those with two or more children. The phase-out rate was also raised, from 14 percent to 21 percent (13 to 16 percent) for taxpayers with two or more children (taxpayers with one child). Overall, the range of the phase-out was expanded dramatically, such that by 1996 a filing unit with two children would still be eligible with income levels of almost $\$ 30,000$. Figure I illustrates the nominal value of the credit from 1984 to 2003, and highlights the dramatic expansion of the credit over time, as well as its effects on the families of different sizes.

These expansions have led to a dramatic and recent increase in the total cost of the EITC. Figure II shows the total cost (in real 2003 dollars) of the EITC from 1974-2003. The figure clearly shows the rising expenditures associated with the 1986, 1990, and 1993 tax acts. Importantly, between 1990 and 1996 the program more than doubled in real terms.

The popularity and perceived success of the EITC can also be seen in the increasing number of states that offer state credits. As of 2004, a total of eighteen states have introduced state EITC's that supplement the federal credit. ${ }^{6}$ Almost all states structure their credits as a share of the federal credit, varying between 5 percent (Illinois) to more than 40 percent (Minnesota and Wisconsin) and almost all make the credit refundable like the federal credit. Table II presents the characteristics of state EITC's along with the date of their introduction. It is notable that several states either introduced or expanded credits since the economic downturn starting in 2000, including Virginia, Indiana, Illinois and Kansas. This continuing growth of state EITCs has been attributed to a recognition among state policymakers that "state EITC's can help working families stay afloat" in difficult labor markets (Llobrera and Zahradnik 2004). The extent to which this is true will depend on the EITC's incidence, however.

An important observation about the EITC is that the credit is based on annual earnings. As a result, its relationship to a worker's hourly wage is indirect. Figure III shows exposure to the credit at different annual hours worked and hourly wages. Among full-time workers, those earning the minimum wage receive the maximum credit, while those earning $\$ 15$ per hour would be just ineligible. Moreover

\footnotetext{
${ }^{6}$ Legislation adopting a state EITC in Virginia was passed in 2004, but will not take effect until January 2006. In addition local governments in Montgomery County, MD, and Denver, CO, offer their own version of EITC's.
} 
the greater generosity of the program for two-child families implies that slightly higher-wage families will be eligible for the credit. This indirect relationship has implications for the interpretation of the empirical evidence. We return to this issue in the discussion section VI.

\section{The EITC Population}

IRS Statistics of Income (SOI) reports can be used to provide a profile of the EITC recipient population. Here we present tabulations of the 2001 Statistics of Income Public Use Tax File, which is a nationally representative sample of all individual tax returns filed in tax year 2001. The file consists of a total of 143,221 records (Internal Revenue Service 2004). We use the tax file data to present tabulations of EITC recipients and costs by filing status, number of children, and earned income.

In 2001, there were a total of 20 million EITC recipients costing a total of 33.3 billion dollars. In Table III, we present tabulations of these recipients and claims by number of children and filing status. The results show that the number of EITC returns is about evenly split between those with one child versus two or more children. Owing to the more generous credit for larger families, however, filers with two or more children receive 61 percent of total EITC dollars (refunds and tax expenditures) while those with one child receive 37 percent of expenditures (the remaining 2 percent funds the small credit for childless filers). The first panel of Table III also shows that single and head of household filers represent fully three-quarters of EITC returns and expenditures while married couples filing jointly make up the remaining quarter. This disproportionate share of unmarried filers among the EITC population reflects the higher eligibility rates—due to lower earnings and income—of single women with children. The third panel of Table III presents the average EITC credit amount by filing status and number of children. The average credit amount rises sharply with number of children- $-\$ 2,459$ for those with two or more children compared to $\$ 1,578$ for those with one child--reflecting the more generous schedule for families with two or more children. In addition, average EITC claims for single parents exceed average payments to married couples filing jointly. As above, this reflects the higher incomes of married couples.

Table IV presents the percent distribution of returns and expenditures for tax filers with children by EITC bracket, using 2001 SOI data. This distribution is the critical determinant of the net labor supply effect of the EITC and its expansion (see discussion in the next section). The table shows that about one quarter of EITC head of household returns and expenditures go to filers in the subsidy (phasein) region of the credit. Far fewer married couples (about 15\%) have income that place them that region of the credit, however. It is useful to separate single and married because the design of the EITC can generate very different labor supply incentives for these two populations. In general, most EITC tax returns are located in the phase-out region of the credit. This is especially true for married couples where 
about half of head of household and more than two-thirds of married couples are in the phase-out region. EITC expenditures show broadly the same pattern, though the distribution is slightly more evenly spread across the regions. About one quarter of EITC benefits for head of household filers go to those in the subsidy region, while about 40-50 percent of benefits go to those in the phase-out region. Among married couples, the data show only 15 percent of dollars benefit those with the lowest-income, while more than half of the dollars go those in the phase-out region.

The SOI reports include a very limited set of observable characteristics of EITC recipients. We expand our discussion by presenting a picture of the EITC population using survey data, which represents the data used in essentially all evaluations of the labor supply effects of the credit. In particular, we provide demographic characteristics of single mothers-who represent the largest group of EITC recipients. Eissa, Kleven and Kreiner [EKK] (2004) provide summary statistics for a sample of single mothers ages 18-49 from the 1986, 1991, 1994 and 2001 March Current Population (CPS) Surveys, covering income and earnings data for the prior calendar year-1985, 1990, 1993, and 2000. The results (presented in Table V) show that the typical single mother during this period is in her early thirties, with a high school diploma, and fewer than two children. In 2000, fully 83 percent of single mothers between the ages of 18-49 in the CPS are working, on average, 1426 hours per year at $\$ 11.24$ per hour. The data also show that the demographic characteristics of the typical eligible single mother have changed little over the period that the EITC has been expanded. Between 1985 and 2000, the typical single mother is aging somewhat over the 15-year period - by just under a year and a half-with fewer children, and more education. The most striking change for single mothers during this period is clearly the increase in labor supply, observed along both the margin of participation and hours worked.

\section{Expected Effects of the EITC}

In this section, we examine the impact of the credit on labor supply discussing the expected impacts on the extensive (employment) and intensive (hours worked by working individuals) margins. ${ }^{7}$ The participation and hours incentives are modeled assuming that taxpayers face no labor market restrictions in their choice of hours, given the (fixed) offered wage. ${ }^{8}$ For simplicity, we consider first the case of an unmarried taxpayer and then extend the analysis to examine labor supply incentives for married couples.

\section{A. Unmarried Taxpayers}

\footnotetext{
${ }^{7}$ Another dimension of labor supply which we do not discuss here is human capital accumulation. This is examined in Heckman, Lochner and Cossa (2002) and reviewed in Hotz and Scholz (2003).

${ }^{8}$ We discuss later the potential impact of the EITC on wages earned by less-skilled workers.
} 
Because the EITC is available only to taxpayers with earned income, standard labor supply theory predicts that the EITC will encourage labor force participation among single parents. The stylized budget constraint, in Figure IV, shows this impact graphically.

The figure plots hours worked (horizontal axis) against income (vertical axis), ignoring for simplicity all other features of the tax-transfer system that affect single parents. ${ }^{9}$ In the absence of the EITC, the taxpayer earns a gross wage $w$ for each hour worked-hence the no-EITC budget constraint is given by segment $\mathrm{AD}$, with slope w. The EITC alters the budget constraint to $\mathrm{ABCD}$. In the phase-in region $(\mathrm{AB})$, the EITC acts as a pure wage subsidy and increases the net wage from $w$ to $w\left(1+\tau_{s}\right)$ where $\tau_{s}$ is the subsidy rate ( 40 percent for taxpayers with two or more children and 34 percent for taxpayers with one child in 2004). In the flat region of the credit (BC), the taxpayer's budget constraint is shifted out an amount equal to the maximum credit ( $\$ 2604$ for taxpayers with one child and $\$ 4300$ for taxpayers with two or more children in 2004) and her gross (and net of tax) hourly wage is w. Each dollar earned in the phaseout region of the EITC (CD) reduces the credit by a phaseout rate of $\tau_{p}$ (about 21 percent). The net wage earned by the taxpayer in this region, $w\left(1-\tau_{p}\right)$, may be reduced even further once the taxpayer starts paying federal tax. This figure is drawn to reflect the fact that phase-out region of the credit is much larger than the phase-in region. For example, for a single women with two children in 2004 the phase-in region spans about 10 thousand dollars (from $\$ 0$ to $\$ 10,750$ ) while the phase-out region spans about 20 thousand dollars (from $\$ 14,040$ to $\$ 34,458$ ).

The figure shows that the well-being of a taxpayer who is not working is not affected by the EITC. Any taxpayer who preferred working before will still prefer working, and some taxpayers may find that the additional after-tax income from the EITC makes it worth entering the labor force. Therefore, the impact of introducing or expanding the EITC on the labor force participation of unmarried taxpayers is unambiguously positive.

The impact of the EITC on the hours worked by a single working taxpayer, however, depends on which region of the credit the woman is in before the credit is expanded or introduced. If she is in the phase-in region, the EITC leads to an ambiguous impact on hours worked due to the negative income effect and positive substitution effect. In the flat region, however, the EITC produces a negative income effect leading to an unambiguous reduction in hours worked. In the phase-out region, the EITC produces a negative income and negative substitution effect leading again to an unambiguous reduction in hours worked. Moreover, the phase-out of the credit alters the budget set in such a way that some taxpayers

\footnotetext{
${ }^{9}$ An important omission here are means tested transfers such as AFDC/TANF and food stamps. These programs have large implicit tax rates and create large disincentives to enter and increase work (Moffitt 1992). Ignoring transfer programs do not affect the qualitative conclusions in this section.
} 
with incomes beyond the phase-out region may choose to reduce their hours of work and take advantage of the credit. Recalling from Table IV above that about three-quarters of single EITC recipients have earnings in the flat and phase-out region of the credit-thus the expectation is that the EITC will reduce the number of hours worked by most eligible single taxpayers already in the labor force.

To illustrate how the EITC affects the incentives faced by single taxpayers, Table VI presents average tax rates faced by hypothetical single taxpayers earning different wage rates, with different family sizes. These calculations are based on the NBER TAXSIM model and cover all federal income taxes and payroll taxes under 2004 law. ${ }^{10}$ We calculate average tax rates for three cases: (1) moving from no work to part time work (20 hours per week, 52 weeks per year); (2) moving from no work to full time work (40 hours per week, 52 weeks per year); and moving from part time to full time work. The average tax rates are calculated with the EITC (columns 1-3) and without the EITC (columns 4-6). The tax rates are calculated for women with one child and two or more children to reflect the different EITC schedules and for women over a range of wage rates from the federal minimum ( $\$ 5.15)$ to $\$ 15$ per hour.

These calculations show that the EITC reduces average tax rates of entering (part and full time) work across all family sizes and all wage levels, thereby illustrating the prediction that participation should unambiguously increase for single parents. The impact of the EITC on these tax rates for entering work can be sizable, even for higher wage women. For example, in tax year 2004 a woman earning $\$ 10$ per hour with two children faces a -25 percent average tax rate (subsidy) for entering work at part time levels and a -3 percent average tax rate (subsidy) for entering work at full time levels. In the absence of an EITC, the same woman would face average tax rates of 15 percent and 10 percent, respectively. The results show that the impacts of the EITC are greatest for lower wage women (with more earnings in the phase-in region), for part time entrants, and for women with two or more children.

The table also illustrates how the EITC penalizes increasing work for those already in the work force. If this woman with two children earning $\$ 10$ per hour were to increase work from part to full time, however, she faces an average tax rate of 18 percent with the EITC (due to the phase-out rate) compared to 10 percent without the EITC. This work disincentive on the intensive (hours) margin exists for all but the lowest wage women (who even at full time work are not yet in the phase-out region of the credit).

In addition to these tax rates for hypothetical taxpayers, Eissa, Kleven and Kreiner (2004) use their CPS sample of single mothers for 1985, 1990, 1993, and 2000 and calculate average and marginal

\footnotetext{
${ }^{10}$ These calculations assume that the individual bears the burden of the entire FICA tax, with a combined marginal tax rate of 15.3 percent. For these calculations, total taxes paid equal federal income tax plus the payroll tax less the (nonrefundable and refundable) child tax credit and the EITC.
} 
tax rates (using TAXSIM) at observed earnings. The results are presented in the bottom of Table $\mathrm{V}$ - and Their results show that the average tax rates declined consistently over the period, from 14.5 percent in 1985 to a negative 4.1 percent in 2000 . It is notable that the time series change in the marginal tax rate is more moderate and less systematic than that of the average tax rate. Note that these tax rates will vary over time due to changes in tax policy (the EITC and all other income tax changes), and also with changes in the earnings and family size of their sample of single women.

EKK also isolate the impact of the federal tax reforms (again EITC and non-EITC tax changes) on tax rates by imputing a post-reform tax rate at given pre-reform characteristics. These results (labeled "Effect of tax act" in Table V) show that all tax acts since 1986 have reduced both the average and marginal tax rates faced by single taxpayers, and have generally reduced tax liability (average tax rates) more significantly than marginal tax rates. The largest reduction in tax rates is due to OBRA93.

\section{B. Married Taxpayers}

In contrast to the predictions for single women, the EITC is expected to reduce the participation and hours worked of most eligible married women. This occurs also because the credit is based on family earnings and income. Suppose family labor supply follows a sequential model, with the husband as the primary earner and the wife as the secondary earner. In this model, the effect of the credit on the labor supply of primary earners is the same as that of single taxpayers-incentives to participate in the labor market strengthen unambiguously while hours of work incentives are ambiguous, though likely negative given the distribution of taxpayer income along the EITC schedule.

The impact of the EITC on secondary earners is more complicated because it depends on the earnings of the primary earner. Assume for simplicity that the husband is the primary earner, and further that his earnings place the family in the phase-out range ${ }^{11}$. The family receives the credit if the wife remains out of the labor force, but the credit amount will decrease with each dollar earned if she enters the labor market. In the phase-out range, therefore, the EITC unambiguously reduces hours worked and participation, by raising family income and reducing the net-of-tax wage. If the husband's earnings place the family in the flat region, the credit unambiguously lowers labor-market participation and hours worked by married women (through a pure income effect). Of course, it is also possible for the wife's work effort to increase the family's credit if the husband's earnings are in the subsidy region (up to $\$ 7,660$ or $\$ 10,750$ in 2004 depending on the number of children), but very few married couples are likely to have incomes in this range.

\footnotetext{
${ }^{11}$ The figures in Eissa and Hoynes (2004) suggest that—-measured by relative earnings—-women are predominantly secondary earners. In a sample of couples with a high school education or less, about 90 percent of all wives, and 85 percent of working wives, earn less than their husbands. In this discussion and in the literature more broadly, women are assumed to be secondary earners.
} 
The impact of the EITC on the labor supply of married couples therefore depends on the distribution of family income along the schedule, the distribution of earnings within the household and the relative elasticities of labor supply with respect to taxes. Secondary earners whose spouses have earnings in the flat and phase-out regions should be less likely to work and should work fewer hours, while those whose spouses have income in the phase-in region should be more likely to work but can increase or reduce their hours worked. Given the distribution of income, it is unlikely the EITC will have any positive effect on the labor supply of married women.

To illustrate the work incentives for married women, Table VII presents average tax rates (using TAXSIM) similar to those presented above for single women. Again the table presents average tax rates for entering and increasing work including and excluding the EITC, and for a range of wages and family sizes. These calculations also require an assumption about the earnings of the husband. We assume that the husband's labor supply is fixed at full-time work and he earns the same hourly wage as his wife. There are two striking observations from the table. First, average tax rates are everywhere higher for married women with the EITC compared to without the EITC. For example, a woman earning $\$ 10$ per hour with two children who enters part time work faces a 36 percent average tax rate with the EITC and a 14 percent tax rate without the EITC. The work disincentive impacts of the EITC extend quite high into the wage distribution reflecting the high breakeven earnings point in the EITC $(\$ 31,338$ for those with one child and $\$ 35,458$ for those with two or more children in 2004). Our assumption of full time work by the husband implies that our calculations do not show any positive participation incentives for women with very low earning husbands. With employment rates for low educated married men approaching 95 percent or higher, however, this is likely to be a small group of women (Eissa and Hoynes, 2004)

Second, married women with children face much higher marginal tax rates compared to single women with children. This occurs in part because the federal tax schedule is progressive, though calculations (in Tables VI-VII) show that the EITC plays an important role. The role of increasing marginal tax rates has been discussed in the taxes and labor supply literature more broadly (e.g., Eissa 1995), but there is less discussion of the EITC in this setting.

\section{What Have we Learned about Labor Supply and the EITC?}

A large body of work has examined both the distributional impacts and the behavioral responses to the Earned Income Tax Credit, including labor supply, family formation and consumption. Perhaps because of its explicit goal of encouraging work, the bulk of this evidence has been on labor supply. Our goal in this discussion is to summarize the major findings in the literature and to discuss their implications for the 
design of tax-transfer programs. Readers interested a more exhaustive summary should see the comprehensive review by Hotz and Scholz (2003).

To presage the main findings, there is overwhelming evidence the EITC encourages work among single mothers but little evidence that eligible-working women adjust their hours of work in response to the EITC. Perhaps most striking about these findings is their consistency across different empirical methods - including both quasi-experimental methods (Eissa and Liebman 1996, Eissa and Hoynes 2004, Hotz, Mullin and Scholz 2002) and more structural methods (Dickert, Houser and Scholz 1995 and Meyer and Rosenbaum 2001) - as well as different EITC expansions.

To interpret and compare the empirical results, we first clarify the different sources of identifying variation. While all individuals face the same tax schedule at any point in time, they face different tax rates based on their filing (i.e. family) status, family size (number of children), non-labor income and earned income (wages and hours worked). Additionally, tax schedules and, therefore, rates vary over time with policy reforms. The main difference between the quasi-experimental approach and more structural methods is the use of group versus individual-level variation in taxes. The first approach assumes that all relevant wage and income changes are captured by group level variation in family type and size (presence and number of children) and time. The EITC effect is the change in employment (relative to that of childless women) of women with children after the EITC expansion. To the extent that tax rates, wages and incomes are measured with error, this grouping approach reduces any measurement error bias in the coefficients of interest.

Most studies take advantage of the large federal expansions in the credit in 1986, 1990, and 1993 that affected incentives for single and married women with children. To control for other factors that may be contemporaneous with the policy changes, many studies utilize control groups and estimate difference-in-difference models. The EITC design and expansions suggest a number of possible strategies—such as comparing women with different family sizes (presence and number of children), marital status, earnings or education levels—for identifying labor supply responses. These models seem to work well and provide robust estimates for the impact of the EITC on participation, but may be less well suited for estimating the impacts on hours worked. Analyzing the determinants of hours worked is more complicated due to the changes in the composition of the working sample and the endogeneity of work more generally. We return to this final point in discussion section VI. First, however, we review the empirical evidence on different margins of labor supply and for different groups.

\section{A. The EITC and the Labor Supply of Single Taxpayers}




\section{Labor Force Participation}

The discussion of labor supply above shows that the EITC is expected to increase the participation of single women with children and reduce the hours worked for the majority of those already in the labor force. Several papers have estimated the impact of the EITC on employment decisions of single women (Dickert, Hauser and Scholz 1995; Eissa and Liebman 1996; Ellwood 2000; Grogger 2003; Hotz et al 2002; Keane and Moffitt 1998; Meyer and Rosenbaum 2000, 2001; Rothstein 2005), all consistently finding that the EITC increased their labor force participation.

Several papers estimate difference-in-difference models applied to a single or multiple expansions of the EITC. In these models, changes in the employment rate of the treatment or eligible group (single women with children) is compared to the change in the employment rate of a control or unaffected group. This approach is used by Eissa and Liebman (EL, 1996), Ellwood (2000), Hotz et al (2002), Meyer and Rosenbaum (MR, 2000), and Rothstein (2005). The most common control group is childless single women (EL 1996, MR 2000, Rothstein 2005). Other comparisons exploit different features of the design of the EITC. Ellwood (2000) and Rothstein (2005) use the fact that the shape of the credit implies different incentives at different hourly wages and compare single mothers at different wage or skill levels. EL (1996), Hotz et al (2002), and Meyer and Rosenbaum (2000) exploit the second child marginal credit and compare single women with one versus those with two or more children.

To illustrate the findings from the difference-in-difference literature, Figure $\mathrm{V}$ presents annual employment rates for women over the period 1984-2003. We show the employment rates for four groups: single women with children, single women without children, married women with children, and married women without children. We use the March CPS for these calculations where employment is defined by any work over the calendar year. ${ }^{12}$ The figure shows the dramatic increase in employment rates for single women with children compared to single women without children. For example, between 1984 and 2003 employment rates of single mothers increased by 12 percentage points-from 73 percent in 1984 to 85 percent in 2003. Most of this change occurred between 1992 and 1999 where employment rates increased by 16 percentage points. This is during the period of the largest expansion in the EITC due to OBRA 1993. Over this same period, there was little change in employment rates of single women without children.

Several authors (Ellwood 2000, Rothstein 2005, Meyer and Rosenbaum 2000) find that the group with the most to gain from EITC expansions (e.g, women with lower wages, lower education levels,

\footnotetext{
${ }^{12}$ We limit the analysis to women ages 19-44, who are not in school or disabled. We also exclude women with positive earnings but zero hours and women with positive hours and zero earnings. Single women are divorced, separated, widowed, or never married and married women include those with spouse present. The results are based on the CPS survey years 1985-2004.
} 
more children, and single women) experienced larger gains in employment rates. To illustrate these findings, the next two figures reproduce results from Meyer and Rosenbaum (2000) and Rothstein (2005). Figure VI reproduces Meyer and Rosenbaum's (2000) difference-in-difference estimates of employment rates for three comparisons-single mothers and single women without children, single mothers and black men, and single mothers and married mothers-where the difference is normalized to 0 in $1984^{13}$. The figure shows that single mothers' employment increased relative to each of these control groups and the gains are well timed to the expansions of the EITC in 1986, 1990 and 1993. Figure VII, reproduced from Rothstein (2005), extends the single mother versus childless single women comparison and estimates difference-in-difference models of the 1993 expansion by wage level. The figure shows that employment increased with OBRA93 for all single mothers relative to childless women and, as expected, the impacts decrease with the woman's wage.

Another approach recognizes that tax-transfer policy has non-neutral effects within groups and used individual variation in net wages and net non-labor income. Consequently, identification is based on cross-sectional and time variation in the EITC and federal taxes. For example, Meyer and Rosenbaum (2001) use instead state-time variation in labor supply incentives and measure the gains to work from wages, net of federal and state taxes, and transfer benefits (AFDC/TANF, Food stamps and Medicaid). ${ }^{14}$

Overall these studies suggest a strong positive relationship between the EITC and employment rates of single women with children. Further, the results are remarkably consistent across different policy expansions, different control groups and different methodologies. The estimated size of the labor supply effect differs depending on the particular expansion considered. Eissa and Liebman (1996) find that the 1986 expansion of the EITC led to a 2.8 percentage point increase in participation (out of a base of 74.2) for single mothers. Meyer and Rosenbaum (2001) find that 60 percent of the 8.7 percentage point increase in annual employment single mothers between 1984 and 1996 is due to the EITC. They find that a smaller amount, 35 percent of the increase in participation between 1992 and 1996 is due to the EITC (with the remainder due to welfare reform and other changes). The range of the implied labor force participation elasticity with respect to net income across all studies is quite narrow-between 0.69 and 1.16 (Hotz and Scholz 2003). ${ }^{15}$

\footnotetext{
${ }^{13}$ Meyer and Rosenbaum's (2000) estimates are based on a sample from the March CPS for 1984-1996. The estimates are from a probit model that includes controls for demographic variables, residential location, unearned income, state unemployment rate (and its interactions with single mother and education level), state and year fixed effects.

${ }^{14}$ Meyer and Rosenbaum (2001) also control for welfare reform variables and state spending on educational training, job search assistance, and child care assistance for AFDC recipients. The gains to work are obtained by integrating over the empirical distribution of wages and hours worked for working women and calculating net income at each wage-hours possibility.

${ }^{15}$ This range excludes the estimates from Hotz et al (2002). Their studies differ from the others in that their sample is limited to welfare recipients (or prior recipients).
} 


\section{Hours Worked}

The EITC is expected to unambiguously reduce hours worked by the vast majority of eligible workers. In sharp contrast to the findings above, however, there is little evidence consistent with this prediction.

A limited set of papers have examined the impact of the EITC on the hours worked by single mothers. This is in part because estimating the hours worked response of workers to the EITC budget constraint is fundamentally a harder empirical problem. In particular, one has to deal with the selection of individuals into the labor force. Eissa and Liebman (1996) apply their difference-in-difference model to annual hours worked (conditional on working) and find a small positive (and marginally significant) impact on all single mothers and a zero impact on low educated single mothers. Meyer and Rosenbaum (1999) find mixed (positive and negative) but insignificant impacts of the EITC on hours worked (conditional on working). Rothstein (2005) finds no difference between single mothers and childless single women in weekly hours worked (conditional on working) across the wage distribution. Keane and Moffitt (1998) estimate a structural model of labor supply choice and simulate the effect of the EITC on total hours but do not present a separate estimate for those already working.

To illustrate the findings from the literature, Figure VIII presents average hours worked (conditional on working) for working single women with and without children over 1984-2003 using our CPS sample described above. Consistent with the studies surveyed, the figure provides no evidence that hours of work decreased for single mothers relative to single women without children as the EITC expanded. Figure IX refines this analysis by focusing in on the phase-out region of the credit where the marginal tax rates are highest. Specifically, the figure plots average earnings for single women with earnings within $\$ 1000$ of the 1996 phase-out region of the credit. Consider a single woman with two children who, in 1984, earned $\$ 15,000$ per year. At that time, she was above the EITC breakeven earnings point. After the 1986 expansions, the same woman (at the same real earnings level) faced a 10 percent EITC phase-out rate. After the 1990 EITC expansions the phase-out rate she faced is about 14 percent and finally after the 1993 expansions the phase-out is up to about 21 percent. Single mothers with earnings in this range (which we adjusted for change in prices each year) are in the range where the tax rates have increased the most. Strikingly, this figure shows no pattern of a reduction in hours worked for single women with children relative to single women without children.

Another source of evidence builds on the prediction from labor supply theory that taxpayers should be bunched at the kinks in the EITC schedule (and should be less present at the end of the EITC schedule). Liebman (1998) and Saez (2002) use tax return data and find no evidence of consistent with 
these predictions. At the end of this section we return to these results and discuss why the literature finds a participation effect but no hours worked effect.

\section{B. The EITC and Labor Supply of Married Taxpayers}

While the literature on married women and the EITC is limited, the results are quite consistent with the theoretical expectations. Eissa and Hoynes (2004) estimate a difference-in-difference model comparing married mothers to married women without children and find that the 1993 EITC expansion led to a one percentage point reduction in the participation rate of married mothers. These results are illustrated in Figure X, reproduced from Eissa and Hoynes (2004), which presents estimates of the change (relative to 1984) in average employment rates for married women with children compared to married women without children (controlling for demographics, macroeconomic cycles and state and year fixed effects). For comparison, the figure also shows the change (relative to 1984) in the average EITC for their sample. This shows that employment by married mothers declined relative to that of childless married women following the 1990 and 1993 expansions (though not the 1986 expansion). This finding is consistent with Ellwood (2000) who compares married mothers in high and low wage quartiles and finds that expansions of the EITC are associated with a reduction in labor market participation by married mothers.

Eissa and Hoynes (2004) also estimate a reduced form employment model for married women (as secondary earners) where they parameterize the impact of the EITC and federal taxes on after-tax gains to entering work. They find that the expansions in the EITC between 1984 and 1996 led to about a one percentage point reduction in the employment of married mothers. These estimates are similar, but somewhat smaller than their difference-in-difference estimates.

Eissa and Hoynes (forthcoming) find that expansions in the EITC are also associated with reductions in hours worked for married women who are working. They estimate hours of work as a function of after tax wages and unearned income, again assuming women are secondary earners. They instrument for the after tax wage using tax parameters. They find that expansions in the EITC from 1984-1996 led to a small, 1 to 4 percent, decrease in annual hours for married women with children. Heim (2005) estimates a structural model of family labor supply and finds similar impacts on hours worked of married women (yet he finds no impact of the EITC on employment of married women).

\section{Discussion}

A. Why Do We Observe a Participation Effect but no Hours Effect?

A consistent and somewhat puzzling finding in the empirical literature on the EITC and labor supply is the large response of the participation decision and the lack of any response by the reported hours worked 
by taxpayers in the labor force. Here we focus on single mothers who, as noted above, represent over three-quarters of EITC recipients.

The puzzle is why no impact on hours worked is found in any evaluation of the EITC. Theory suggests that we should observe a decline in the hours worked by all taxpayers beyond the phase-in of the credit. While the income effect operates to reduce hours worked in the flat region, both income and substitution effects operate to reduce hours worked in the phase-out region of the credit.

We review several explanations that have been offered. The first explanation is based on a standard finding in the empirical labor supply literature, which is that the labor supply elasticity falls when estimated using a sample of working (rather than all) women (Mroz 1987, Triest 1990). The implication of this finding is that the participation (extensive) margin is more responsive than the hours (intensive) margin. It may well be that the hours worked elasticity is too small to be estimated precisely using quasiexperimental approaches. If, for example, the elasticity of hours worked by single women with children is 0.3, then the 1993 EITC expansion would reduce hours of work by 8 percent. ${ }^{16}$ It is not unreasonable to consider this reduction as too small to be identified empirically, especially given the somewhat crude comparison-of-means approach typically used. If this is correct, then the next question is-why is the elasticity on the intensive margin consistently lower than the extensive margin?

One reason why there may be no effect of the EITC on hours-worked is that workers are unable to choose continuous hours of work. This would occur if, for example, workers are bound by institutional restrictions or by norms for part time and full time work. ${ }^{17}$ To examine the validity of this explanation, Figure XI presents the distribution of annual hours worked for our CPS sample of single mothers in 1986, 1990, 1993, and 2000. (Note this includes all single mothers and, in particular, is not limited to those with earnings in the EITC eligible range.) Two observations are worth noting. First, annual hours are highly concentrated at full-time work. While some single mothers work part-time (primarily part-year), the majority of single mothers work full-time (full year). Second, the increase in employment mirrors the increase in full-time, full-year work. One (testable) interpretation of this trend is that new workers enter the labor market at full-time work—consistent with a labor supply model with large fixed costs of work.

Another reason why no hours-worked effect has been estimated is that reported hours in the survey data are measured with error (Bound and Krueger 1991, Bound, Brown, and Mathiowetz 2001).

\footnotetext{
${ }^{16}$ The 1993 expansion in the EITC increased the phase-out rate to 21.06 (15.98) percent from 13.93 (13.21) percent for families with one child (two or more children). Assuming the woman faces a 15 percent marginal tax rate and the full 15.30 percent FICA rate, this implies a 13 percent reduction in the net of tax wage.

${ }^{17}$ Alternatively, one can argue that a worker can change jobs as an additional way to change hours.
} 
Annual hours of work are typically constructed as the product of weeks worked last year times usual hours worked per week last year. Other than standard recall error, individuals with varying weekly hours may make errors in averaging.

Finally, taxpayers may not be fully aware of the structure of the EITC schedule. Almost all taxpayers receive the EITC as a lump sum payment with their annual tax return (Friedman 2000), and therefore have little opportunity to learn about the features of the credit. This may be especially true for the phase-out region of the credit, in part because of the confounding effects of non-EITC federal income taxes. This EITC structure and its delivery are in contrast to the monthly reporting period in welfare programs and to the weekly or biweekly paycheck and its opportunities for learning about FICA or ordinary income taxes. Further, informal and formal surveys of EITC eligibles suggest that knowledge about the credit is relatively high, though by no means universal (Liebman 1998, Phillips 2001, Smeeding et al 2000, Romich and Weisner 2000). Phillips, for example, finds that about 66 percent of families nationally had heard of the EITC. There is scant evidence, however, that those likely eligible for the credit understand its structure or the different incentives implied.

\section{B. Implications for Optimal Tax and Welfare}

The finding that labor force participation responses are more significant than hours worked responses has several important implications for the design of tax-transfer programs and the welfare evaluation of taxation. Recent work has shown accounting for a labor force participation responses can change the optimal transfer program (Saez, 2002). More precisely, this work has shown that with sufficiently high participation elasticities, the optimal tax-transfer scheme can be similar to the EITC - with negative marginal tax rates at the bottom of the earnings distribution. An EITC would, on the other hand, be inefficient in a standard model with only intensive (hours worked) responses. ${ }^{18}$

Liebman (2002) extends on this work by examining more closely the optimal design of the EITC. He uses a micro-simulation model calibrated to 1999 CPS data to illustrate the trade-offs in the design of an EITC -including the optimal maximum credit, phase-in and phase-out rates- with fixed costs and participation effects. Liebman finds that the efficiency cost of transferring income through the EITC is substantially lower than previous studies have found, in large part because of the participation response of single mothers and the associated reduced welfare spending. His simulations suggest a cost of less than $\$ 2$ to provide a transfer worth $\$ 1$ to EITC recipients.

\footnotetext{
${ }^{18}$ Saez shows that the optimal program is instead a classical Negative Income Tax program, with a substantial income guarantee that is phased out a high rate.
} 
Eissa, Kleven and Kriener (2005) take a different approach and examine the impact of participation responses on the welfare evaluation of actual tax reforms. They extend the standard framework for welfare evaluation of tax reforms to account for discrete labor market entry by way of nonconvexities in preferences and budget sets. Such non-convexities are significant because they allow firstorder welfare effects along the extensive (participation) margin. EKK simulate the effects of the 1986, 1990, 1993 and 2001 tax acts in the United States and show that each had different effects on tax rates along the intensive and extensive margins. The 1993 EITC expansion, for example, reduced the tax rates on labor force participation, but increased the marginal tax rates on hours worked for most workers. The authors show that conflating these two tax rates in welfare analysis can be fundamentally misleading. For tax reforms that change average tax rates differently than marginal tax rates (such as the 1993 expansion of the EITC), ignoring the participation margin can lead to even the wrong sign of the welfare effect.

\section{Incidence}

Understanding the effects of the EITC on wages is directly relevant to evaluating the effectiveness of the EITC, and its longer run effects of labor supply. If the EITC reduces gross wages below what they would have been otherwise, the credit may do little, if anything to encourage labor supply, and may operate to the primary benefit of low-wage employers.

Recent work by Leigh (2004) and Rothstein (2005) directly examine the effect of the EITC on pre-tax wages, using very different methods. Leigh uses variation across states in the presence and generosity of state EITC add-ons and finds a very strong negative effect of the credit on wages, implying very little benefit of the credit for its recipients. One drawback to Leigh's approach is that state EITC's are small relative to the federal program, and many recipients may not be aware of their existence. As a consequence behavioral responses may be muted, making it difficult to identify the incidence of the credit. Rothstein uses variation from the 1993 federal credit expansion along the wage distribution and finds that low-skill women's wages actually increased slightly even as their labor force participation increased. These results imply an upward-sloping demand curve, though they are by no means sufficiently precise to reject a small downward slope. One possible explanation for the conflicting findings of the Leigh and Rothstein studies is the different sources of identification. Clearly more work needs to done to increase our understanding of the broader labor market effects of the EITC.

\section{Conclusions}

An unusual feature of the credit is its explicit goal to use the tax system to encourage and support those who choose to work. A large body of work has evaluated the labor supply effects the EITC and has generated several important findings regarding the behavioral response to taxes. This paper reviews this empirical literature, focusing on two main lessons. It argues that perhaps the main lesson learned from 
the evidence is the confirmation that real responses to taxes are important; labor supply does respond to the EITC. The second major lesson is related to the nature of the labor supply response, namely that that the response is concentrated along the extensive (entry) margin, rather than the intensive (hours worked) margin. We discuss different explanations of this pattern of labor supply responses, and discuss its implications for the optimal design of tax-transfer programs and for the welfare evaluation of tax reforms.

Empirical evidence suggests that transferring dollars to the needy using an EITC - rather than a Negative Income Tax - may be optimal. This evidence cannot yet support more precise judgments about the optimal design of the EITC, however. That would require - among other things - identifying the hours of work response of workers to the EITC. 


\section{References}

Bound, John, Charles Brown, and Nancy Mathiowetz, "Measurement Error in Survey Data," in Handbook of Econometrics, vol. 5, eds. James J. Heckman and Edward Leamer, Amsterdam: North Holland, 2001.

Bound, John, and Alan B. Krueger, "The Extent of Measurement Error in Longitudinal Earnings Data: Do Two Wrongs Make a Right?" Journal of Labor Economics, January 1991, 9, 1-24.

Dickert, Stacy, Scott Houser and John Karl Scholz (1995). "The Earned Income Tax Credit and Transfer

Programs: A Study of Labor Market and Program Participation." In Tax Policy and the Economy. James Poterba, ed. Cambridge: MIT Press.

Eissa, Nada (1995). "Taxation and Labor Supply of Married Women: The Tax Reform Act of 1986 as a Natural Experiment," NBER Working Paper 5023.

Eissa, Nada and Hilary Hoynes (2004). "Taxes and the Labor Market Participation of Married Couples: The Earned Income Tax Credit," Journal of Public Economics, Volume 88, Issues 9-10, Pages 1931-1958, August 2004.

Eissa, Nada and Hilary Hoynes (forthcoming). "The Hours of Work Response of Married Couples: Taxes and The Earned Income Tax Credit," CESifo/MIT Press conference volume, Tax Policy and Labor Market Performance, Peter Birch Sorensen ed.

Eissa, Nada, Henrik Kleven, and Claus Kreiner (2004) "Evaluation of Four Tax Reforms in the United States: Labor Supply and Welfare Effects for Single Mothers” NBER-WP 10935.

Eissa, Nada and Jeffrey Liebman (1996). "Labor Supply Response to the Earned Income Tax Credit." Quarterly Journal of Economics, CXI, 605-637.

Eissa, Nada, Austin Nichols and Jesse Rothstein (2005). "Tax-Transfer Schemes and Wages:

The Earned Income Tax Credit." Paper presented at AEA/NEA Session "Skills, Policy, and Labor Market Outcomes across Demographic Groups."

Ellwood, David (2000). "The Impact of the Earned Income Tax Credit and Social Policy Reforms on Work, Marriage and Living Arrangements," National Tax Journal 53(4) Part 2 (December).

Friedman, Pamela (2000) “The Earned Income Tax Credit” Welfare Information Network, Issue Notes.

Grogger, Jeffrey (2003). "The Effects of Time Limits, the EITC, and Other Policy Changes on Welfare Use, Work, and Income among Female-Headed Families," Review of Economics and Statistics, Volume 85, Issue 2, May 2003

Heckman, James, Lance Lochner and Ricardo Cossa (2002). "Learning-By-Doing vs. On-The-JobTraining: Using Variation Induced by the EITC to Distinguish Between Models of Skill Formation." NBER-WP 9083.

Heim, Bradley (2005). "The Impact of the Earned Income Tax Credit on the Labor Supply of Married Couples: Structural Estimation and Business Cycle Interactions," mimeo, Duke University, May 2005.

Hotz, V. Joseph, Charles Mullin and John Karl Scholz (2002). "The Earned Income Tax Credit and the Labor Market Participation of Families on Welfare," Mimeo, UCLA.

Hotz, V. Joseph and John Karl Scholz (2003). "The Earned Income Tax Credit" in Robert Moffitt, ed., Means-Tested Transfer Programs in the United States. Chicago: University of Chicago Press. 
Internal Revenue Service (2004). General Description Booklet for the 2001 Public Use Tax File, Statistics of Income Division.

Keane, Michael and Robert Moffitt (1998). "A Structural Model of Multiple Welfare Program Participation and Labor Supply," International Economic Review 39(3):553-589.

Leigh, Andrew (2004). "Who Benefits from the Earned Income Tax Credit? Incidence Among Recipients, Coworkers and Firms." Mimeo, Australian National University.

Liebman, Jeffrey (1998). "The Impact of the Earned Income Tax Credit on Incentives and the Income Distribution." In Tax Policy and the Economy 12. James Poterba, ed. Cambridge: MIT Press.

Liebman, Jeffrey (2002). "The Optimal Design of the Earned Income Tax Credit," in Making Work Pay: The Earned Income Tax Credit and Its Impact on American Families. Ed. Bruce D. Meyer and Douglas HoltzEakin. Russell Sage Foundation, 2002.

Llobrera and Zahradnik (2004). "A hand up: How state earned income tax credits help working families escape poverty in 2004”. Washington, DC: Center for Budget and Policy Priorities.

Meyer, Bruce and Dan Rosenbaum (1999). "Welfare, the Earned Income Tax Credit, and the Labor Supply of Single Mothers." NBER Working Paper 7363.

Meyer, Bruce and Dan Rosenbaum (2000). "Making Single Mothers Work: Recent Tax and Welfare Policy and its Effects." National Tax Journal 53(4) Part 2 (December).

Meyer, Bruce and Dan Rosenbaum (2001). "Welfare, the Earned Income Tax Credit, and the Labor Supply of Single Mothers." Quarterly Journal of Economics, Vol. 116, Issue 3 (August).

Moffitt, Robert (1992). "Incentive Effects of the U.S. Welfare System: A Review." Journal of Economic Literature 15(1):1-61.

Mroz, Thomas (1987). "The Sensitivity of an Empirical Model of Married Women's Hours of Work to Economic and Statistical Assumptions," Econometrica 55:765-799.

Phillips, Katherin Ross (2001). "Who Knows about the Earned Income Tax Credit?" New Federalism, National Survey of America's Families, Series B, No. B-27. The Urban Institute.

Romich, Jennifer and Thomas Weisner (2000). "How Families View and Use the EITC: Advance Payment versus Lump Sum Delivery." National Tax Journal, Vol 53(4), Part 2.

Rothstein, Jesse (2005). "The Mid-1990s EITC Expansion: Aggregate Labor Supply Effects and Economic Incidence," mimeo, Princeton Unversity.

Saez, Emmanuel (2002). "Do Taxpayers Bunch at Kink Points?" Mimeo, University of California, Berkeley.

Smeeding, Timothy, Katherin Ross Phillips, and Michael O'Connor (2000). "The EITC: Expectation, Knowledge, Use, and Economic and Social Mobility." National Tax Journal, Vol 53(4), Part 2.

Triest, Robert (1990). "The Effect of Income Taxation on Labor Supply in the United States," The Journal of Human Resources, XXV, 491-516. 
U.S. House of Representatives (2004). "Background Materials and Data on Programs within the Jurisdiction of the Committee on Ways and Means." Government Printing Office, Washington, DC. 
Figure I

Earned Income Tax Credit, 1984-2003

(A) Schedule for Family with One Child

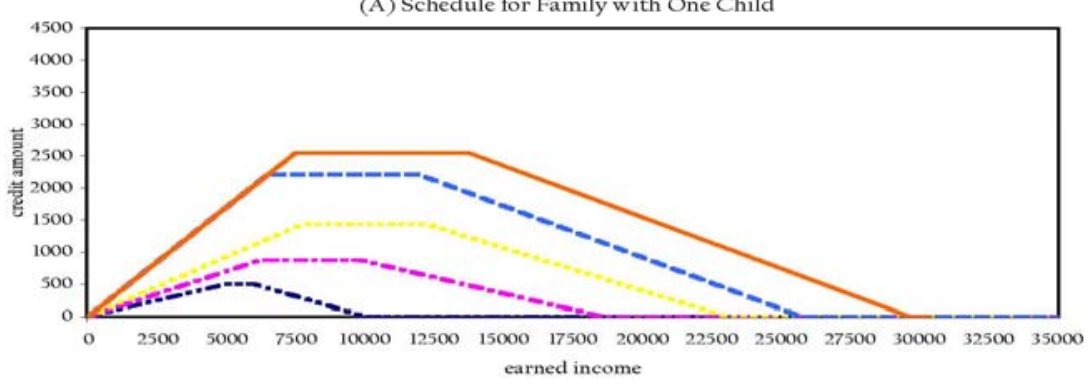

(B) Schedule for Family With Two + Children

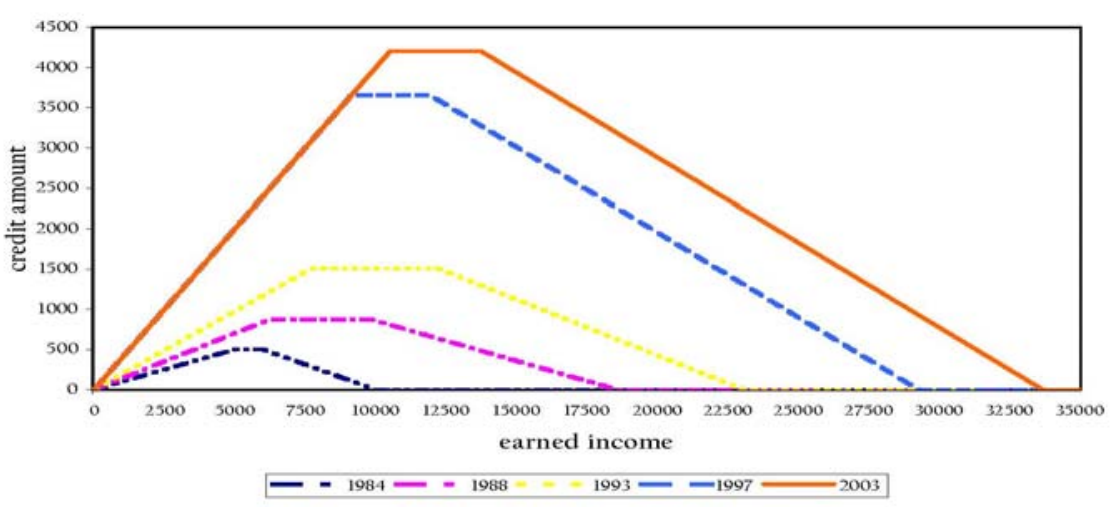

Notes: Authors' tabulations using tax parameters in Table I. 
Figure II

Real Spending on the EITC (Billions of 2003 Dollars)

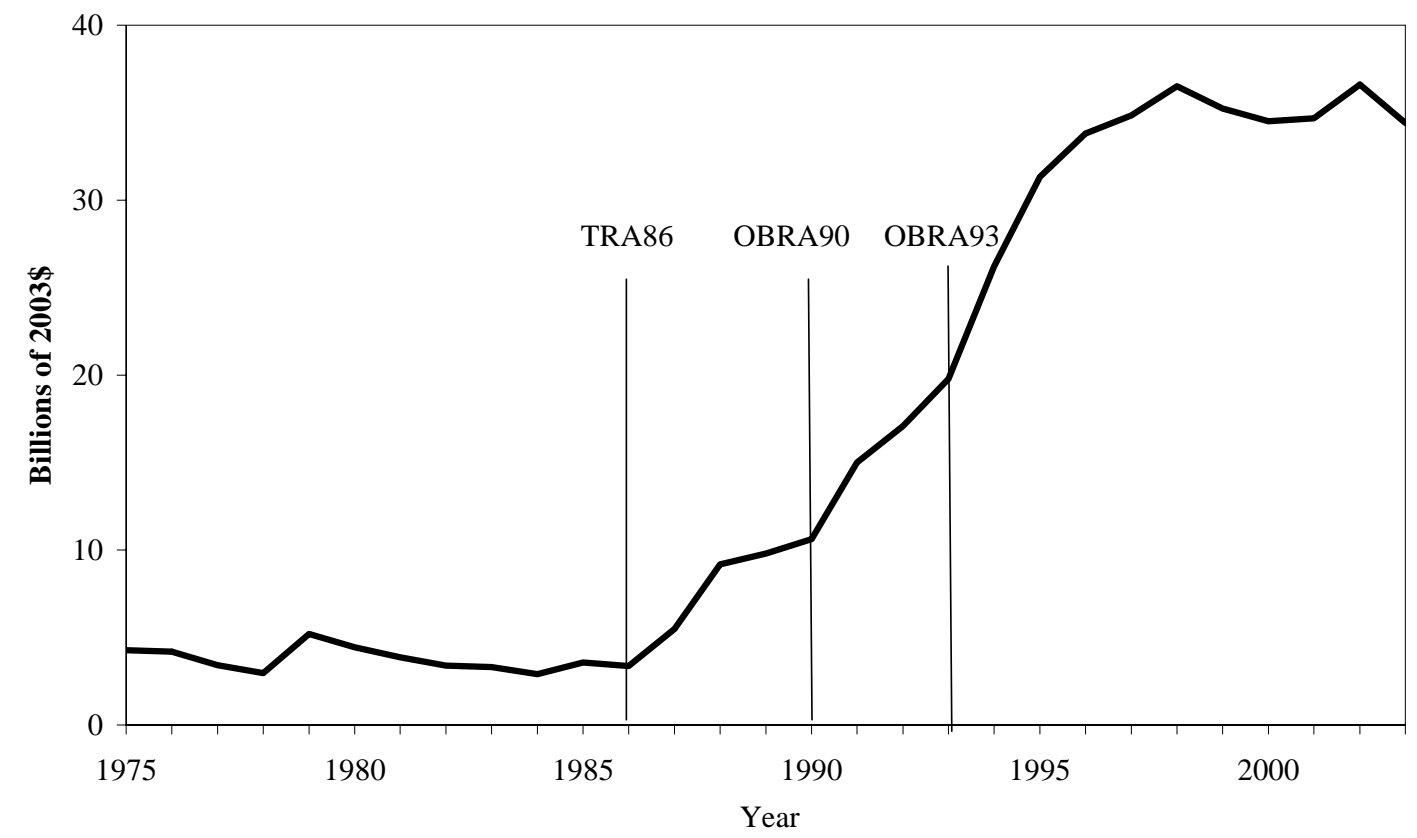

Source: U.S. House of Representatives (2004), Table 13-14. 
Figure III

EITC Benefit for Selected Hourly Wage Levels, by Annual Hours Worked (2004 Tax Year)
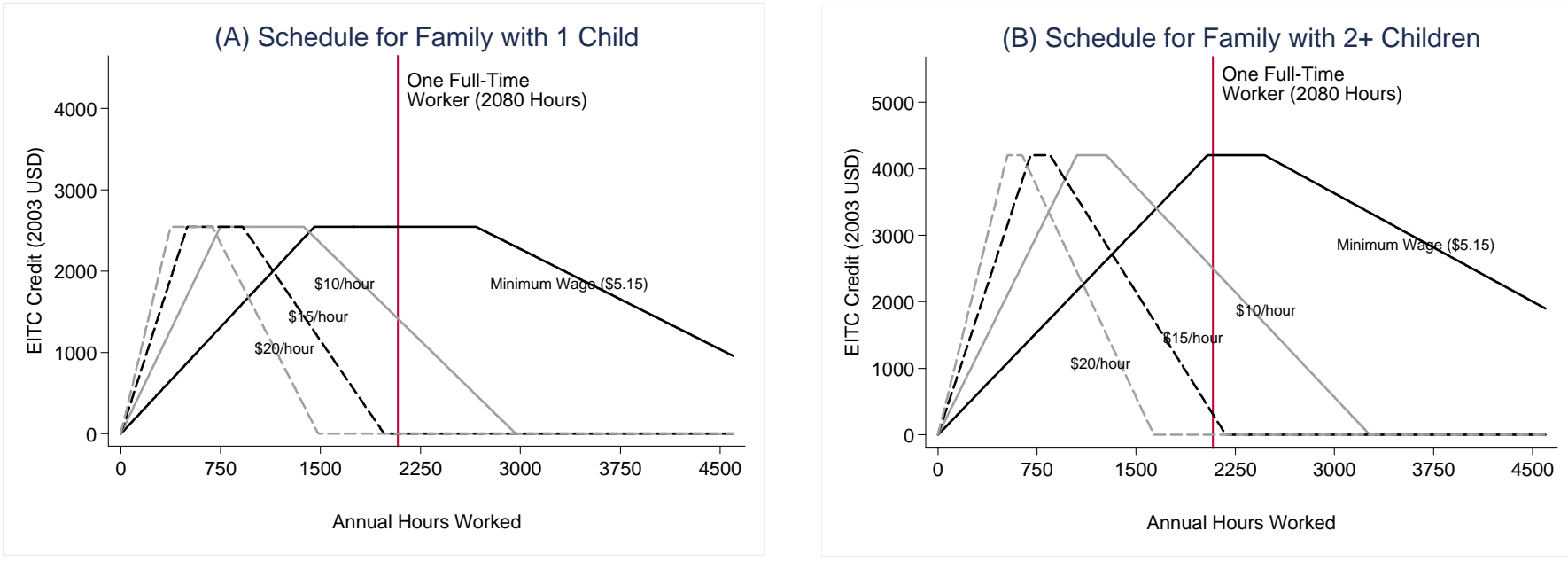

Source: Eissa, Rothstein and Nichols (2005). Figure shows the value of the EITC by wage level and annual hours worked assuming that there is one worker in the family and no other sources of income. 
Figure IV

Stylized Budget Constraint for the EITC

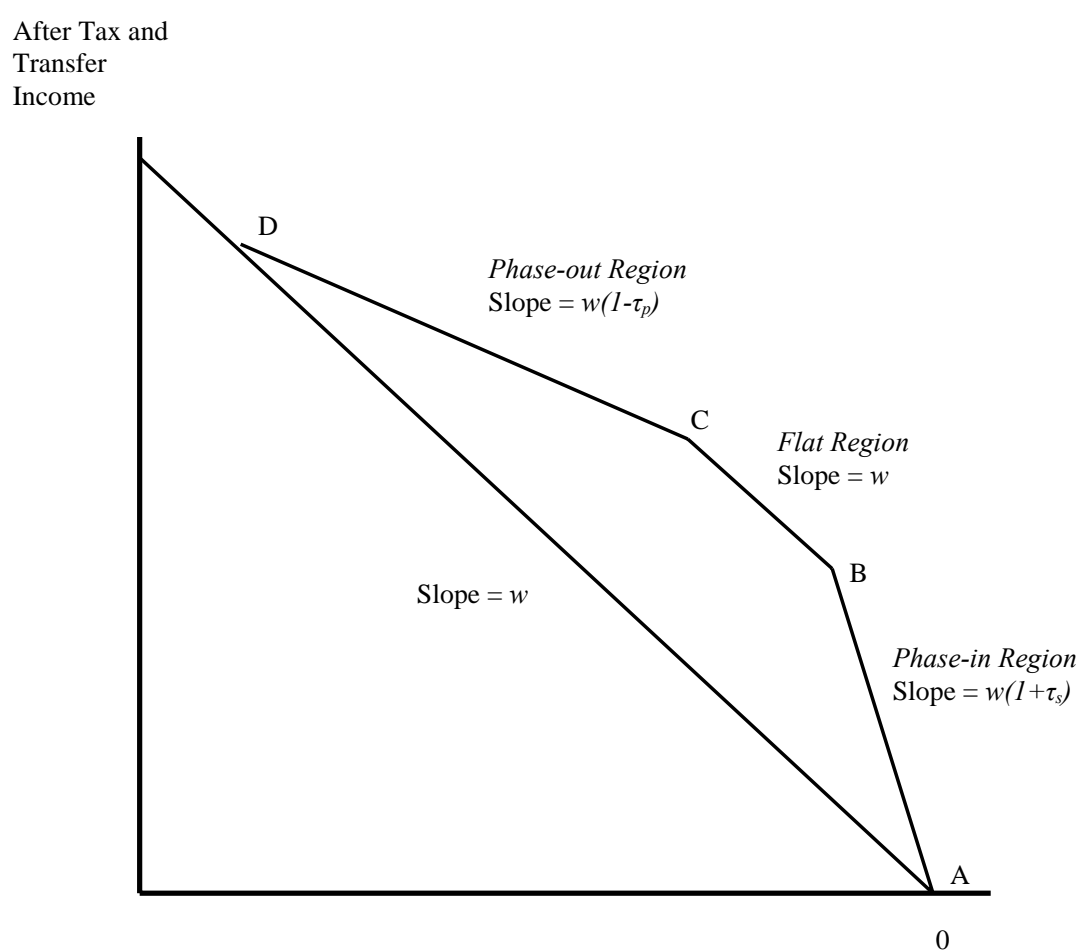

Hours of Work 
Figure $\mathrm{V}$

Annual Employment Rates for Women

By Marital Status and Presence of Children, 1984-2003

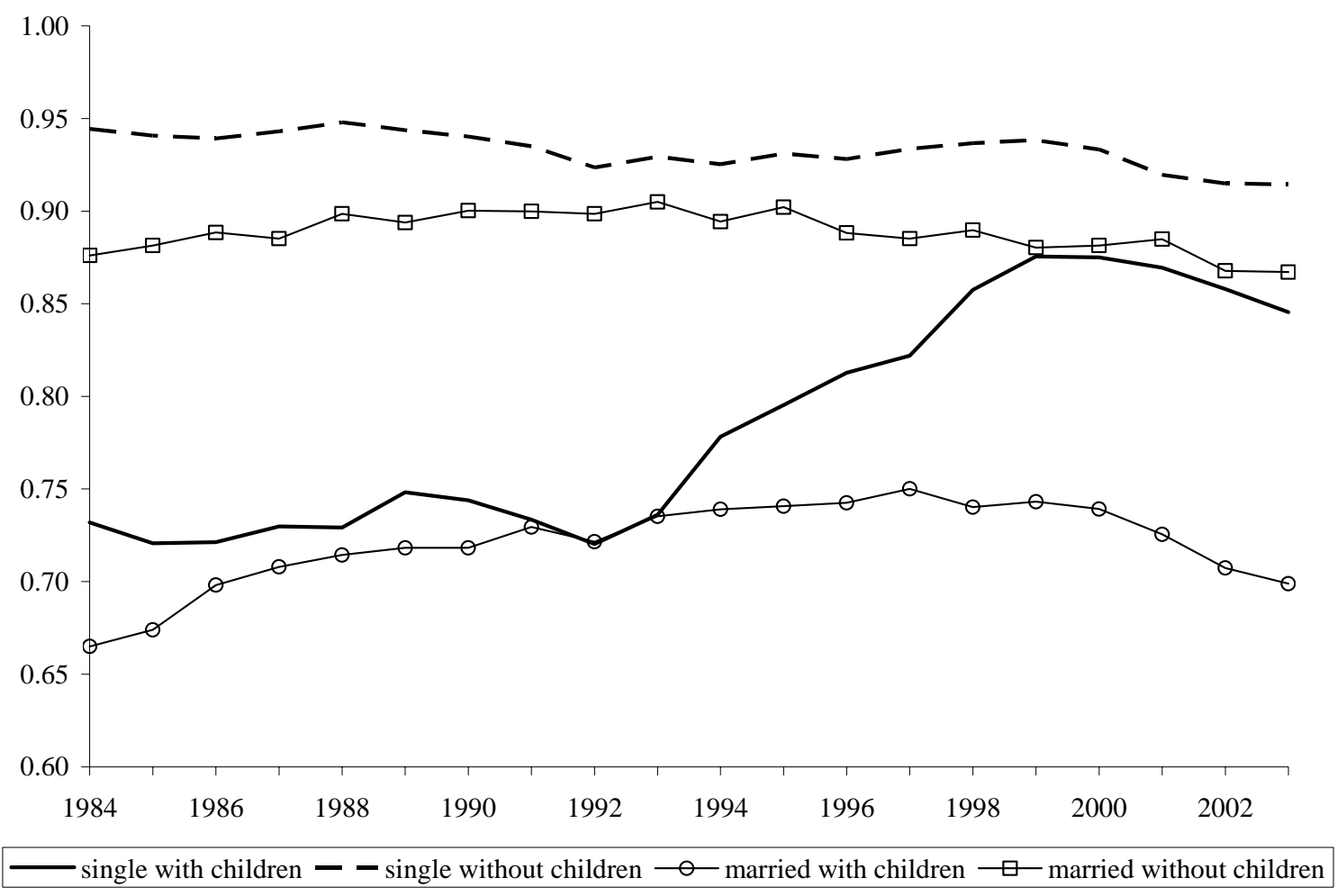

Notes: Calculations based on the 1985-2004 March CPS and include women ages 19-44, not in school and not disabled. It also excludes women with positive earnings but zero hours and those with positive hours and zero earnings. Married women include those with spouse present and single women include divorced, widowed and never married women. Figure shows the fraction of women who worked at all in the calendar year. 
Figure VI

Difference-in-Difference Estimates of Annual Employment Rates

Single Mothers versus Control Groups, 1984-1996

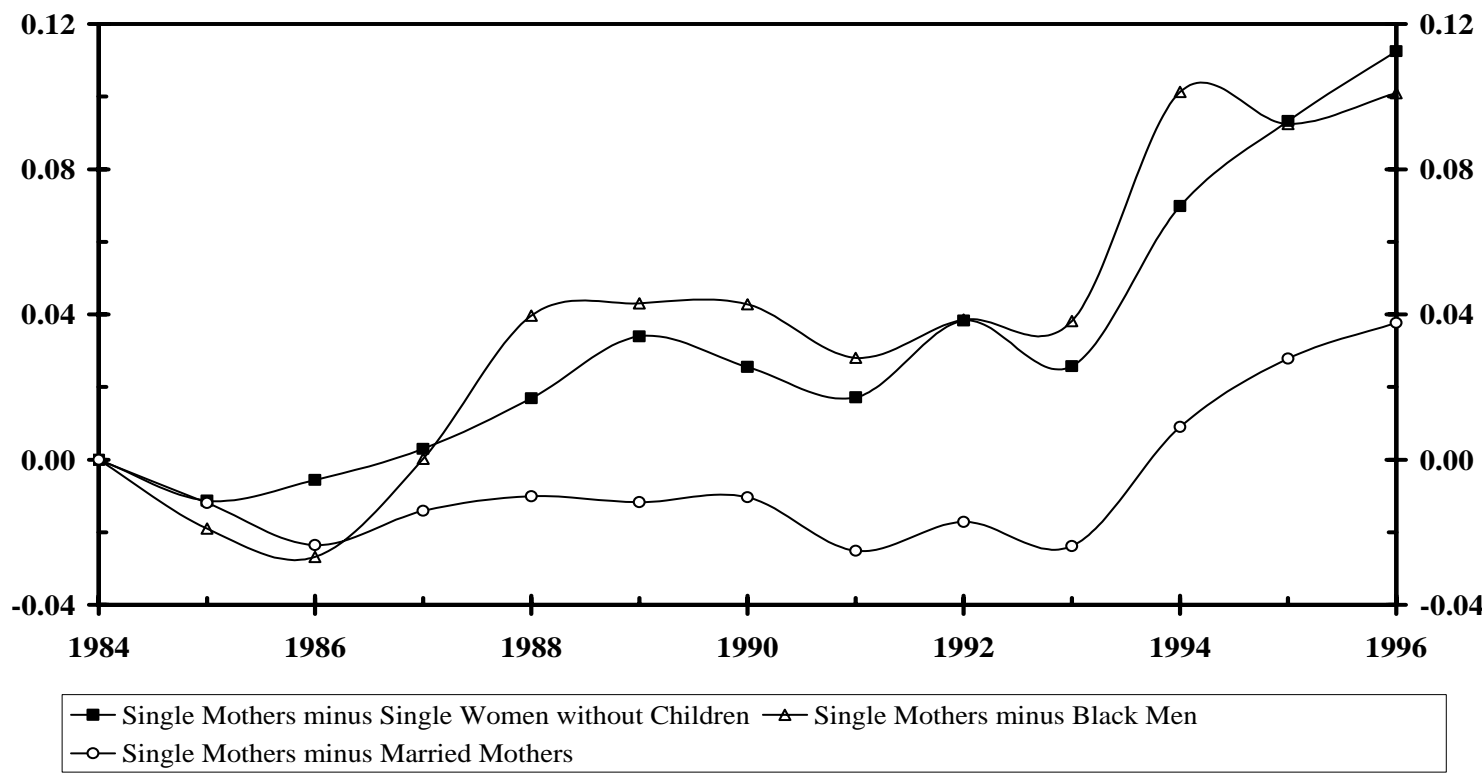

Note: Reproduced from Meyer and Rosenbaum (2000), Figure 9. Treatment group includes single women ages 19-44 from the March CPS for 1985-1997. Each line represents the difference in employment rates between the treatment group (single mothers) and one of three control groups. The estimates are from a probit model that controls for demographic variables, residential location, unearned income, state unemployment rate (and its interactions with single mother and education level), state and year fixed effects. 
Figure VII

Difference-in-Difference Estimates of OBRA93 on Annual Employment Rates, by Wage Level Single Mothers versus Single Women without Children

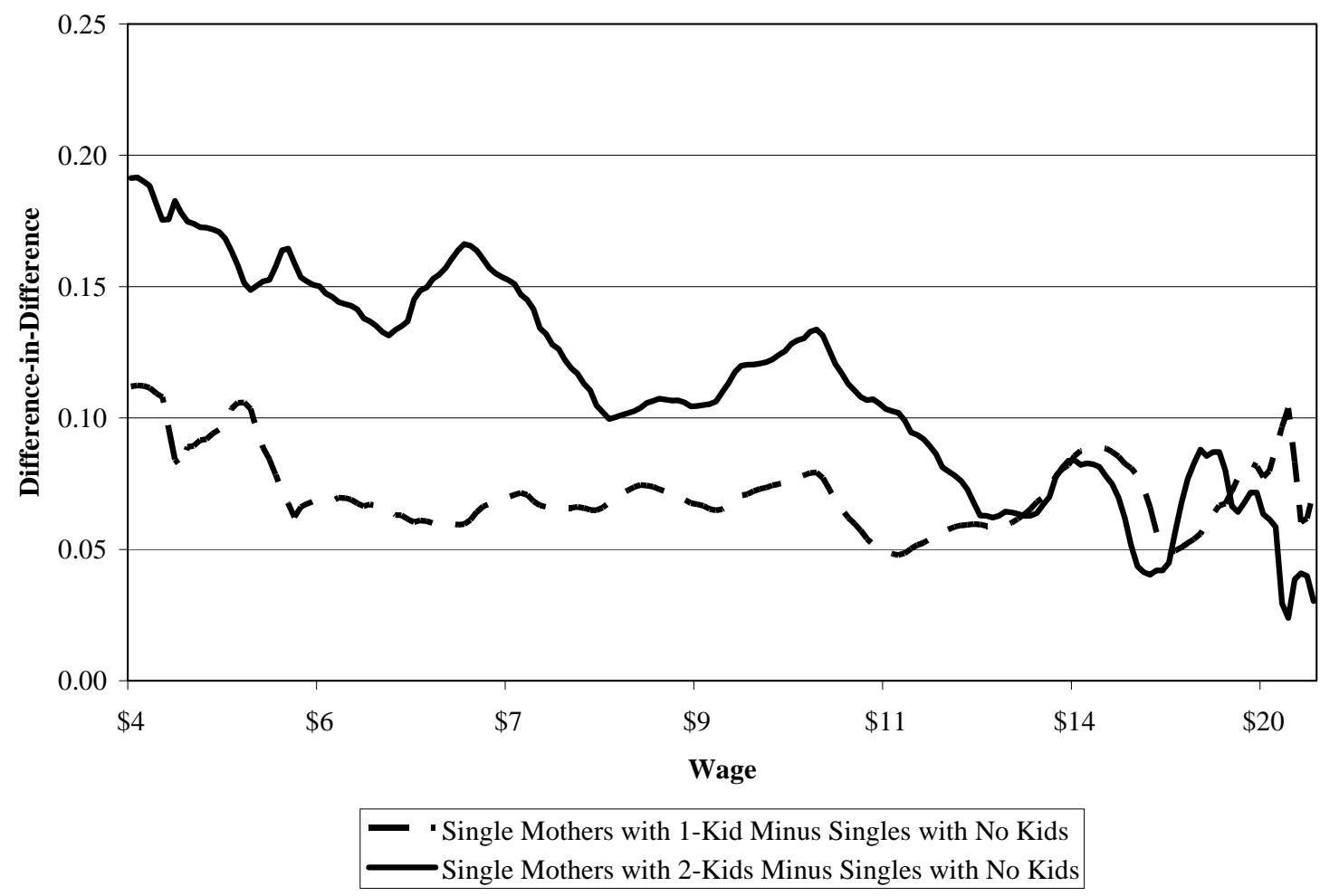

Note: Reproduced from Rothstein (2005), Figure 10. Sample includes women ages 19-64 from the March CPS. The Pre-OBRA93 period is 1992-1993 and the post-OBRA93 period is 1996-1997. Each line represents the difference in employment rates between the treatment group (single mothers with one or two or more children) and the control group (single women without children). The estimates are from a semi-parametric model that controls for education, potential experience, race/ethnicity, number and presence of children, and residence. 
Figure VIII

Average Annual Hours Worked for Working Single Women by Presence of Children, 1984-2003

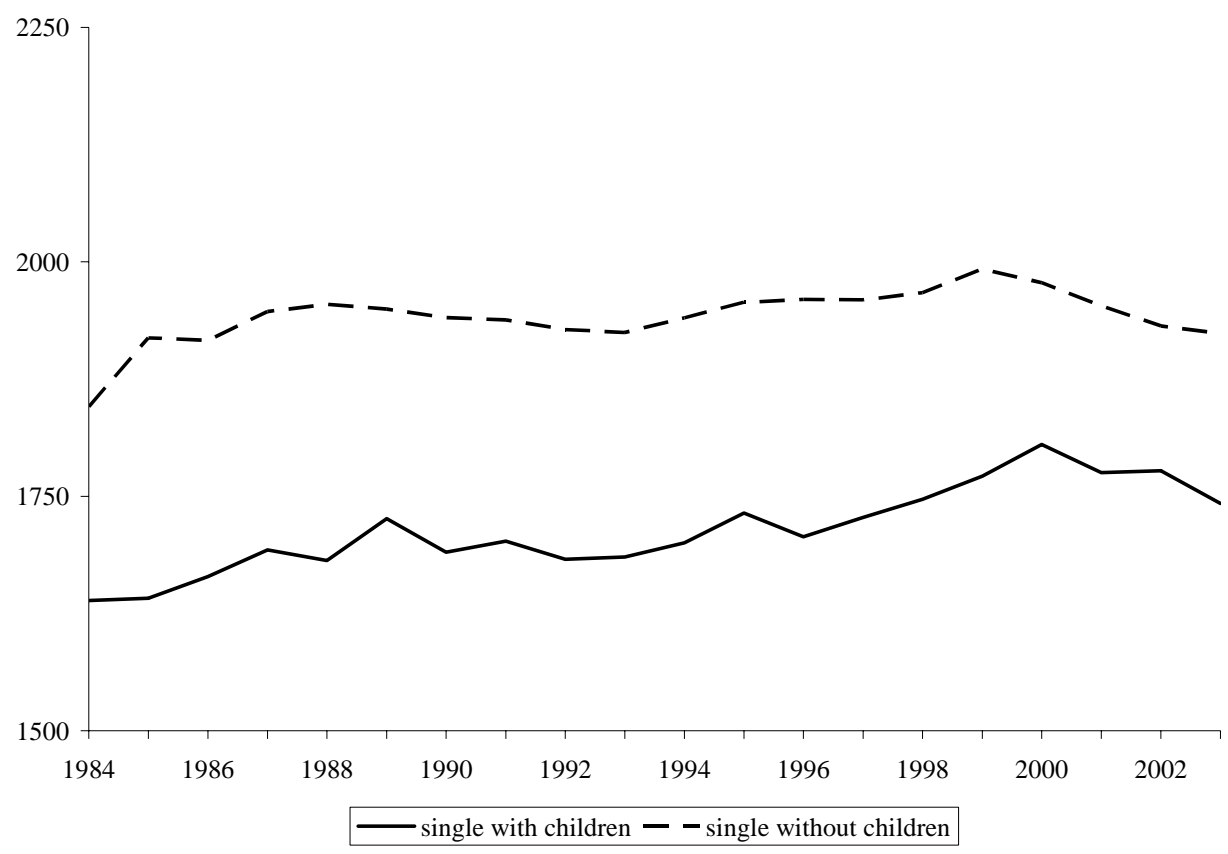

Notes: Calculations based on the 1985-2004 March CPS and include single women ages 19-44, not in school, not disabled, who worked at all during the calendar year. It also excludes women with positive earnings but zero hours and those with positive hours and zero earnings. Single women include divorced, widowed and never married women. Figure shows average annual hours worked conditional on working. 
Figure IX

Average Annual Hours Worked for Single Women in the Phase-out Region of the EITC, 1984-2003 By Presence of Children

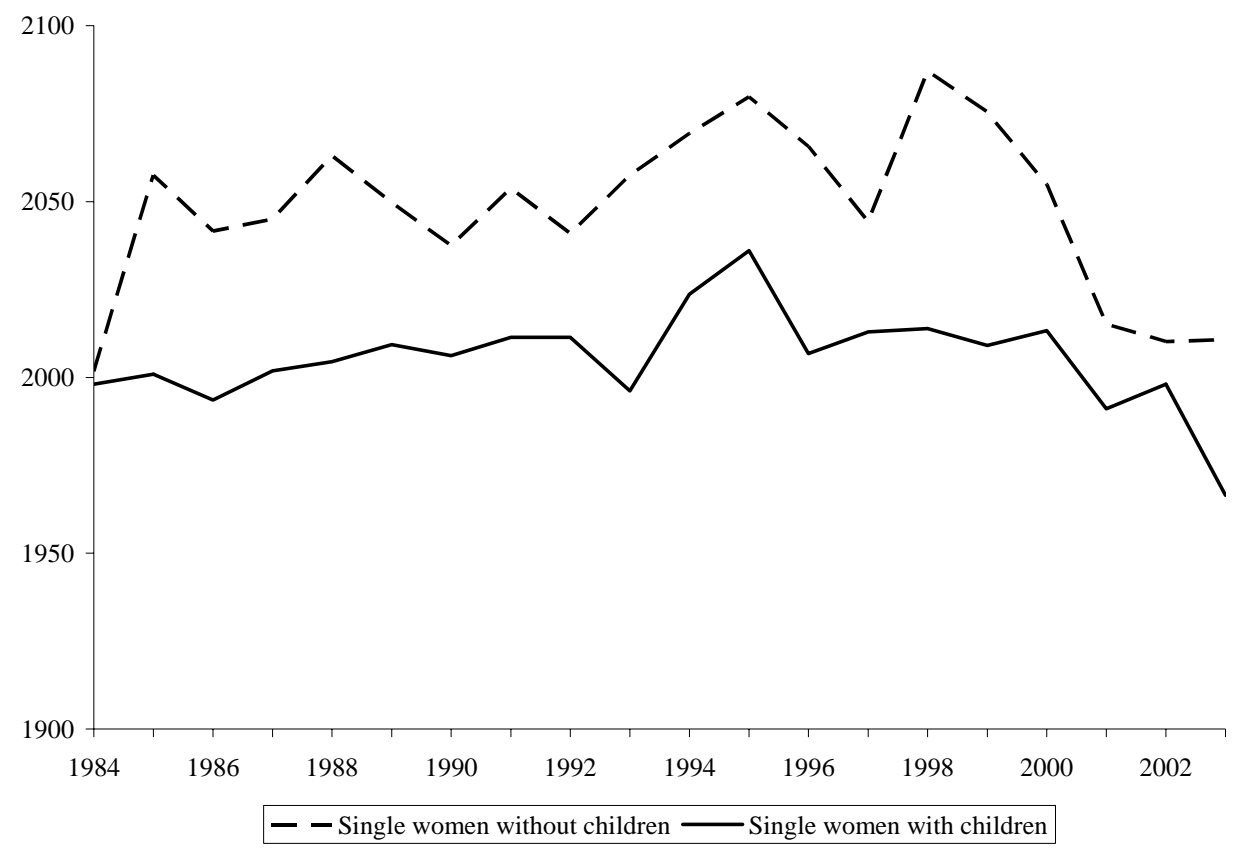

Notes: Calculations based on the 1985-2004 March CPS and include single women ages 19-44, not in school and not disabled. It also excludes women with positive earnings but zero hours and those with positive hours and zero earnings. Single women include divorced, widowed and never married women. The figure shows average annual hours worked for the sample of single women who have earnings within $\$ 1000$ of the 1996 phase-out region of the EITC (in real terms). 
Figure $\mathrm{X}$

Difference-in-Difference Estimates of Annual Employment Rates, 1984-1996

Married Mothers versus Married Women without Children

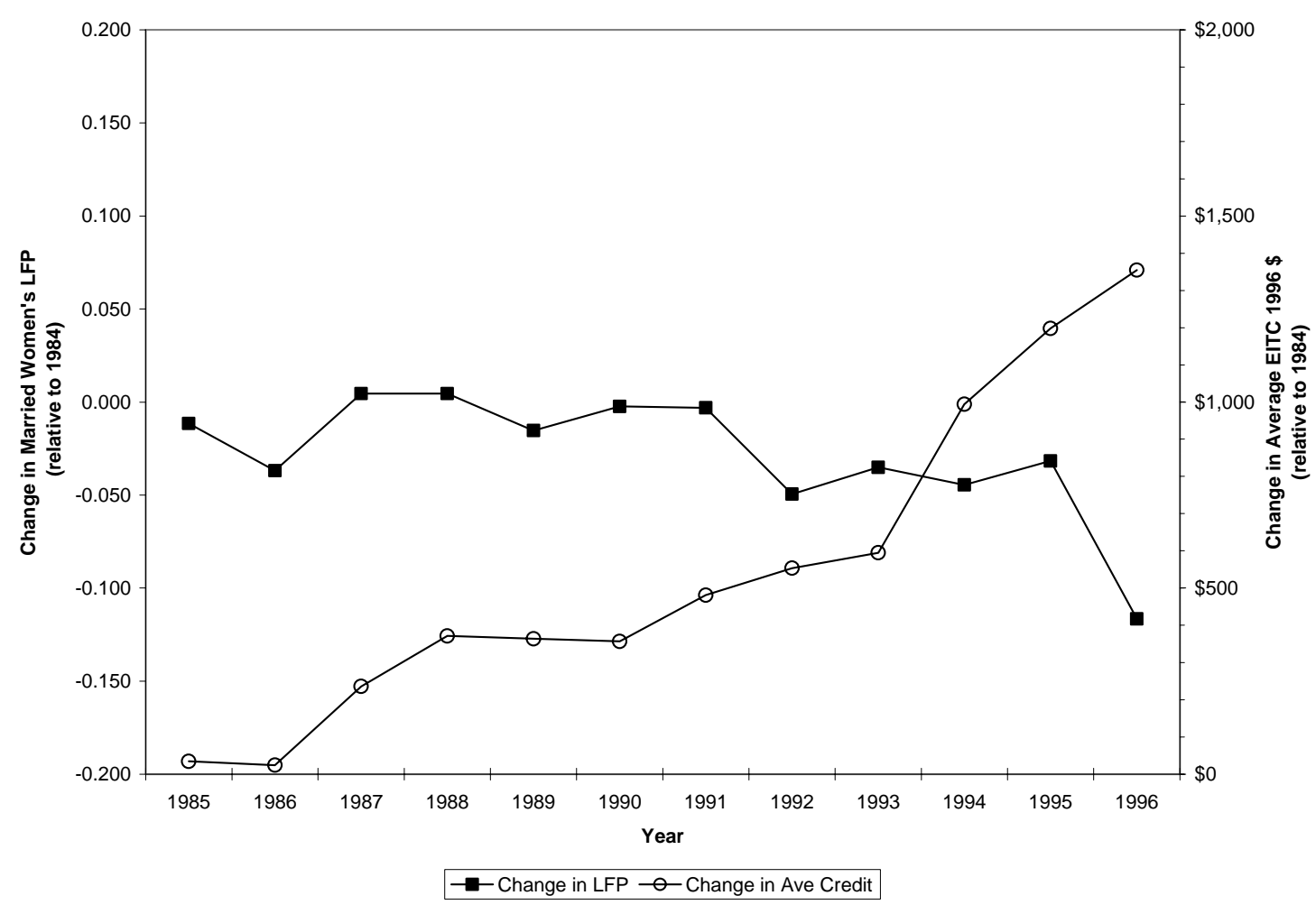

Note: Reproduced from Eissa and Hoynes (2004), Figure 5. Sample includes married women ages 25-54 with less than a high school education from the March CPS for 1985-1997. The sample excludes couples where one spouse was ill or disabled, in the military, or in school full time during the previous year. The line with square markets gives the change (relative to 1984) in average annual employment rates for married women with children compared to married women without children. The estimates are from a probit model that controls for demographic variables, state dummies, state labor market variables, and year effects for both groups. The line with a circle marker gives the change (relative to 1984) in the average credit calculated for a secondary earner (the wife) for a fixed (1996) distribution of husband's earnings. 
Figure XI

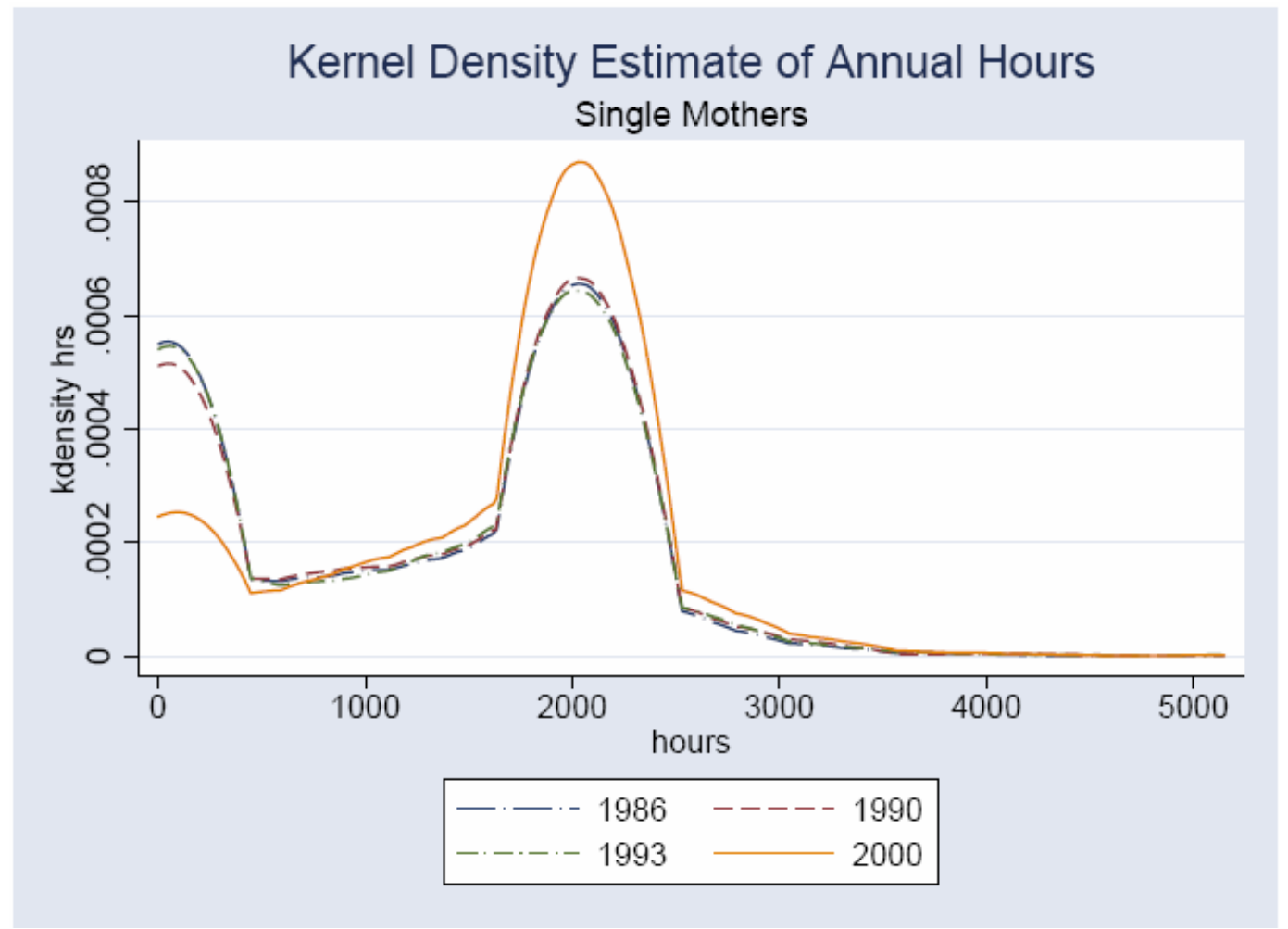

Notes: Reproduced from Eissa, Kleven and Kreiner (2004), using March CPS sample of single women with children, ages 19-44, not in school, and not disabled. It also excludes women with positive earnings but zero hours and those with positive hours and zero earnings. Single women include divorced, widowed and never married women. Figure provides a smoothed estimate of the distribution of annual hours worked (nonworkers have annual hours equal to 0 ). 
TABLE I

FEDERAL INCOME TAX AND EITC PARAMETERS, 1984-2005

\begin{tabular}{|c|c|c|c|c|c|c|}
\hline \multirow{3}{*}{ Year } & \multicolumn{2}{|c|}{ Federal Income Tax Parameters } & \multicolumn{4}{|c|}{ EITC Parameters } \\
\hline & \multirow[t]{2}{*}{$\begin{array}{l}\text { [lowest marginal } \\
\text { tax rate; highest } \\
\text { marginal tax } \\
\text { rate] }\end{array}$} & \multirow[t]{2}{*}{$\begin{array}{c}\text { Personal Exemption, } \\
\text { Standard } \\
\text { Deduction }^{\mathrm{a} / \mathrm{b} /}\end{array}$} & $\begin{array}{l}\text { Phase-In } \\
\text { Rate }\end{array}$ & Maximum Credit & $\begin{array}{l}\text { Phase-Out } \\
\text { Rate }\end{array}$ & $\begin{array}{c}\text { Maximum } \\
\text { Earnings }\end{array}$ \\
\hline & & & \multicolumn{4}{|c|}{ (family with one child; family two or more children) } \\
\hline 1984 & {$[0.000 ; 0.500]$} & $\$ 1,000 ; \$ 0$ & 0.100 & $\$ 500$ & 0.125 & $\$ 10,000$ \\
\hline 1985 & {$[0.000 ; 0.500]$} & $\$ 1,040 ; \$ 0$ & 0.110 & $\$ 550$ & 0.122 & $\$ 11,000$ \\
\hline 1986 & {$[0.000 ; 0.500]$} & $\$ 1,080 ; \$ 0$ & 0.110 & $\$ 550$ & 0.122 & $\$ 11,000$ \\
\hline \multicolumn{7}{|c|}{ TRA86 } \\
\hline 1987 & {$[0.110 ; 0.390]$} & $\$ 1,900 ; \$ 2,540$ & 0.140 & $\$ 851$ & 0.100 & $\$ 15,432$ \\
\hline 1988 & {$[0.150 ; 0.330]$} & $\$ 1,950 ; \$ 4,400$ & 0.140 & $\$ 874$ & 0.100 & $\$ 18,576$ \\
\hline 1989 & {$[0.150 ; 0.330]$} & $\$ 2,000 ; \$ 4,550$ & 0.140 & $\$ 910$ & 0.100 & $\$ 19,340$ \\
\hline 1990 & {$[0.150 ; 0.330]$} & $\$ 2,050 ; \$ 4,750$ & 0.140 & $\$ 953$ & 0.100 & $\$ 20,264$ \\
\hline \multicolumn{7}{|c|}{ OBRA90 c/ } \\
\hline 1991 & {$[0.150 ; 0.310]$} & $\$ 2,150 ; \$ 5,000$ & $0.167 ; 0.173$ & $\$ 1,192 ; \$ 1,235$ & $0.119 ; 0.124$ & $\$ 21,250$ \\
\hline 1992 & {$[0.150 ; 0.310]$} & $\$ 2,300 ; \$ 5,250$ & $0.176 ; 0.184$ & $\$ 1,324 ; \$ 1,384$ & $0.126 ; 0.131$ & $\$ 22,370$ \\
\hline 1993 & {$[0.150 ; 0.396]$} & $\$ 2,350 ; \$ 5,450$ & $0.185 ; 0.195$ & $\$ 1,434 ; \$ 1,511$ & $0.132 ; 0.139$ & $\$ 23,050$ \\
\hline \multicolumn{7}{|c|}{ OBRA1993 d/ } \\
\hline 1994 & {$[0.150 ; 0.396]$} & $\$ 2,450 ; \$ 5,600$ & $0.263 ; 0.300$ & $\$ 2,038 ; \$ 2,528$ & $0.160 ; 0.177$ & $\$ 23,755 ; \$ 25,296$ \\
\hline 1995 & {$[0.150 ; 0.396]$} & $\$ 2,500 ; \$ 5,750$ & $0.340 ; 0.360$ & $\$ 2,094 ; \$ 3,110$ & $0.160 ; 0.202$ & $\$ 24,396 ; \$ 26,673$ \\
\hline 1996 & {$[0.150 ; 0.396]$} & $\$ 2,550 ; \$ 5,900$ & $0.340 ; 0.400$ & $\$ 2,152 ; \$ 3,556$ & $0.160 ; 0.211$ & $\$ 25,078 ; \$ 28,495$ \\
\hline 1997 & {$[0.150 ; 0.396]$} & $\$ 2,650 ; \$ 6,050$ & $0.340 ; 0.400$ & $\$ 2,210 ; \$ 3,656$ & $0.160 ; 0.211$ & $\$ 25,750 ; \$ 29,290$ \\
\hline 2000 & {$[0.150 ; 0.396]$} & $\$ 2,900 ; \$ 6,650$ & $0.340 ; 0.400$ & $\$ 2,353 ; \$ 3,888$ & $0.160 ; 0.211$ & $\$ 27,413 ; \$ 31,152$ \\
\hline \multicolumn{7}{|c|}{ EGTRRA2001 ${ }^{e /}$} \\
\hline 2002 & {$[0.100 ; 0.386]$} & $\$ 3,050 ; \$ 7,000$ & $0.340 ; 0.400$ & $\$ 2,547 ; \$ 4,204$ & $0.160 ; 0.211$ & $\$ 29,201 ; \$ 33,178$ \\
\hline 2004 & {$[0.100 ; 0.35]$} & $\$ 3,100 ; \$ 7,150$ & $0.340 ; 0.400$ & $\$ 2,604 ; \$ 4,300$ & $0.160 ; 0.211$ & $\$ 30,338 ; \$ 34,458$ \\
\hline 2005 & {$[0.100 ; 0.35]$} & $\$ 3,200 ; \$ 7,300$ & $0.340 ; 0.400$ & $\$ 2,662 ; \$ 4,400$ & $0.160 ; 0.211$ & $\$ 31,030 ; \$ 35,263$ \\
\hline
\end{tabular}

a/ The standard deductions are given for head of household tax return.

b/ In 1984-1986, there were no standard deductions because of the zero bracket. The 15 brackets include the zero bracket.

c/ Basic EITC only. Does not include supplemental young child credit or health insurance credit.

$\mathrm{d} /$ Introduced a small benefit for taxpayers with no qualifying children, phased-in at 0.0765 up to a maximum credit of $\$ 306$.

e/ The flat and phase-out regions are expanded by $\$ 2000$ (\$1000) in 2005 (2002-2004) for married couples filing jointly.

Source: U.S. House of Representatives [The Green Book] (various years) and authors' calculations from Internal Revenue Service (IRS) forms and publications. 
TABLE II

STATE EARNED INCOME TAX CREDITS, 2004

\begin{tabular}{ll}
\hline \hline State & Percentage of Federal Credit (2004) \\
\hline Refundable Credits & \\
Colorado (1999) & $10 \%$ (suspended until 2006) \\
District of Columbia (2000) & $25 \%$ \\
Illinois (2000) & $5 \%$ \\
Indiana (1999) & $6 \%$ (starting in 2003) \\
Kansas (1998) & $15 \%$ \\
Maryland* (1987) & $20 \%$ \\
Massachusetts (1997) & $15 \%$ \\
Minnesota (1991) & Varies with earnings; averages 33\% \\
New Jersey (2000) & $20 \%$ (for families with earnings below $\$ 20,000)$ \\
New York (1994) & $30 \%$ \\
Oklahoma (2002) & $5 \%$ \\
Vermont (1988) & $32 \%$ \\
Wisconsin (1989) & $4 \%$ (one child);14\% (two children);43\% (three children) \\
Non-refundable Credits & \\
Iowa (1990) & \\
Maine** (2000) & $6.5 \%$ \\
Oregon (1997) & $4.92 \%$ \\
Rhode Island (1975) & $5 \%$ \\
Virginia (2004) & $25 \%$ \\
& $20 \%$ (effective 2006) \\
\hline \hline
\end{tabular}

* Maryland also offers a non-refundable EITC set at 50 percent of the credit. Taxpayers in effect may claim either the refundable credit or the non-refundable credit, but not both.

**Maine's non-refundable EITC was reduced from 5\% to 4.92\% effective in tax years 2003, 2004 and 2005. The credit will return to 5\% in 2006.

***Rhode Island made a very small portion of its EITC refundable effective beginning in tax year 2003.

Source: Llobrera and Zahradnik (2004) and www.stateEITC.info (State EITC Online Info Center). 
Table III

Percent Distribution of EITC Returns and Claims by Filing Status and Number of Qualifying Children, 2001

\begin{tabular}{|c|c|c|c|}
\hline & \multicolumn{3}{|c|}{ Number of Qualitfying Children } \\
\hline & None & One & $\begin{array}{c}\text { Two or } \\
\text { More }\end{array}$ \\
\hline \multicolumn{4}{|c|}{ Percent Distribution of EITC Returns } \\
\hline Head of Household Filers ${ }^{1}$ & $16 \%$ & $33 \%$ & $28 \%$ \\
\hline Married Filing Joint Filers & $2 \%$ & $7 \%$ & $14 \%$ \\
\hline All filers & $18 \%$ & $40 \%$ & $42 \%$ \\
\hline \multicolumn{4}{|c|}{ Percent Distribution of Total EITC Claims } \\
\hline Head of Household Filers ${ }^{1}$ & $2 \%$ & $32 \%$ & $43 \%$ \\
\hline Married Filing Joint Filers & $0 \%$ & $6 \%$ & $17 \%$ \\
\hline All filers & $2 \%$ & $37 \%$ & $61 \%$ \\
\hline \multicolumn{4}{|l|}{ Average EITC Claim } \\
\hline Head of Household Filers $^{1}$ & $\$ 205$ & $\$ 1,615$ & $\$ 2,612$ \\
\hline Married Filing Joint Filers & $\$ 205$ & $\$ 1,403$ & $\$ 2,144$ \\
\hline All filers & $\$ 205$ & $\$ 1,578$ & $\$ 2,459$ \\
\hline
\end{tabular}

Source: Tabulations from Tax Policy Center, Urban Institute using 2001 Statistics of Income Public Use Tax File.

$1 /$ Includes individuals who file as single. 
Table IV

Distribution of EITC Recipients and Claims by EITC Range, 2001

\begin{tabular}{|c|c|c|c|c|}
\hline & \multicolumn{4}{|c|}{ EITC Earnings by EITC Range } \\
\hline & Phase-in & Flat & Phase-out & All \\
\hline \multicolumn{5}{|c|}{ Percent Distribution of EITC Recipients by EITC Range } \\
\hline \multicolumn{5}{|l|}{$\underline{\text { Head of Household Filers }}$} \\
\hline One Child & $23 \%$ & $25 \%$ & $52 \%$ & $100 \%$ \\
\hline Two or More Children & $28 \%$ & $15 \%$ & $57 \%$ & $100 \%$ \\
\hline \multicolumn{5}{|l|}{ Married Filing Joint Filers } \\
\hline One Child & $14 \%$ & $22 \%$ & $64 \%$ & $100 \%$ \\
\hline Two or More Children & $15 \%$ & $10 \%$ & $75 \%$ & $100 \%$ \\
\hline \multicolumn{5}{|c|}{ Percent Distribution of EITC Claims by EITC Range } \\
\hline \multicolumn{5}{|l|}{ Head of Household Filers } \\
\hline One Child & $21 \%$ & $37 \%$ & $42 \%$ & $100 \%$ \\
\hline Two or More Children & $27 \%$ & $23 \%$ & $50 \%$ & $100 \%$ \\
\hline \multicolumn{5}{|l|}{$\underline{\text { Married Filing Joint Filers }}$} \\
\hline One Child & $14 \%$ & $37 \%$ & $49 \%$ & $100 \%$ \\
\hline Two or More Children & $17 \%$ & $19 \%$ & $64 \%$ & $100 \%$ \\
\hline
\end{tabular}

Notes: Tabulations from Tax Policy Center, Urban Institute using 2001 Statistics of Income Public Use Tax File. 
Table V

Demographic Characteristics and Tax Rates for Single Mothers, 1985-2000

\begin{tabular}{lcccc}
\hline Year & 1985 & 1989 & 1992 & 2000 \\
\hline $\begin{array}{l}\text { Demographic Characteristics } \\
\text { Age }\end{array}$ & $32.04(7.75)$ & $32.91(7.77)$ & $32.98(7.79)$ & $33.44(8.15)$ \\
Education & & & \\
\% 12 or more years of & $0.784(0.411)$ & $0.773(0.418)$ & $0.793(0.406)$ & $0.787(0.409)$ \\
schooling & $0.321(0.467)$ & $0.345(0.475)$ & $0.338(0.473)$ & $0.315(0.464)$ \\
Black & $0.021(0.142)$ & $0.023(0.151)$ & $0.031(0.172)$ & $0.037(0.188)$ \\
Non-white & $1.94(1.10)$ & $1.77(0.99)$ & $1.78(1.0)$ & $1.74(0.93)$ \\
Number of children & $0.707(0.455)$ & $0.72(0.447)$ & $0.697(0.459)$ & $0.830(0.376)$ \\
Labor force participation & $1142(961)$ & $1219(969)$ & $1148(970)$ & $1426(903)$ \\
Annual hours worked & $\$ 7,922(9,210)$ & $\$ 10,390(11,642)$ & $\$ 10,572(12,740)$ & $\$ 16,430(19,526)$ \\
Wage and salary income & $\$ 2,756(4,605)$ & $\$ 3,277(5,742)$ & $\$ 3,553(5,912)$ & $\$ 3,961(7,740)$ \\
Non-labor income & $\$ 6.53(4.43)$ & $\$ 7.85(5.49)$ & $\$ 8.68(7.00)$ & $\$ 11.24(10.68)$ \\
Gross hourly wage & & & & \\
& & & & \\
Tax Rates & & & & \\
Marginal tax rate & $0.259(0.166)$ & $0.216(0.175)$ & $0.185(0.212)$ & $0.231(0.288)$ \\
Average tax rate & $0.145(0.105)$ & $0.088(0.089)$ & $0.042(0.010)$ & $-0.041(0.180)$ \\
Effect of Tax Act & TRA1986 & OBRA1990 & OBRA1993 & EGGTRA2001 \\
marginal tax rate & $-0.059(0.095)$ & $-0.017(0.051)$ & $-0.033(0.142)$ & $-0.034(0.071)$ \\
average tax rate & $-0.076(0.029)$ & $-0.053(0.016)$ & $-0.128(0.076)$ & $-0.023(0.014)$ \\
Observations & & & & \\
& 4,498 & 4,850 & 5,011 & \\
\hline \hline
\end{tabular}

Source: Eissa, Kleven and Kreiner (2005). Calculations based on March CPS and include single mothers ages 18-49. Non-labor income is calculated as the difference between total income and earnings, and therefore includes income for various sources such as welfare assistance, capital income, social security income and workers' compensation. The wage is defined for workers only and is topcoded at \$200 in 2000. Tax rates are calculated using NBER's TAXSIM model and include all federal income taxes and the payroll tax (assuming individuals bear the entire tax). Calculations for "effect of tax act" use sample for a fixed year and calculates tax rates under old law and new law-the differences are reported. Standard errors are in parenthesis. All monetary amounts are in nominal dollars. 
Table VI

Average Tax Rates for Hypothetical Single Women with Children (2004 tax law)

Taxes Calculated with and without the EITC

\begin{tabular}{|c|c|c|c|c|c|c|}
\hline & \multicolumn{3}{|c|}{ Average Tax Rates with the EITC } & \multicolumn{3}{|c|}{ Average Tax Rates without the EITC } \\
\hline & $\begin{array}{r}\text { Entry to PT } \\
\text { work } \\
\end{array}$ & $\begin{array}{r}\text { Entry to FT } \\
\text { work } \\
\end{array}$ & $\begin{array}{r}\text { PT to } \\
\text { FT work } \\
\end{array}$ & $\begin{array}{r}\text { Entry to PT } \\
\text { work } \\
\end{array}$ & $\begin{array}{r}\text { Entry to FT } \\
\text { work } \\
\end{array}$ & $\begin{array}{r}\text { PT to } \\
\text { FT work } \\
\end{array}$ \\
\hline \multicolumn{7}{|c|}{ A. Single taxpayer with one child (by hourly wage level) } \\
\hline$\$ 5.15 / \mathrm{hr}$ & $-19 \%$ & $-9 \%$ & $1 \%$ & $15 \%$ & $15 \%$ & $15 \%$ \\
\hline$\$ 7.50 / \mathrm{hr}$ & $-18 \%$ & $-3 \%$ & $12 \%$ & $15 \%$ & $12 \%$ & $12 \%$ \\
\hline$\$ 10 / \mathrm{hr}$ & $-10 \%$ & $7 \%$ & $23 \%$ & $15 \%$ & $14 \%$ & $14 \%$ \\
\hline$\$ 12 / \mathrm{hr}$ & $-7 \%$ & $13 \%$ & $33 \%$ & $14 \%$ & $16 \%$ & $16 \%$ \\
\hline$\$ 15 / \mathrm{hr}$ & $-3 \%$ & $19 \%$ & $41 \%$ & $12 \%$ & $19 \%$ & $19 \%$ \\
\hline \multicolumn{7}{|c|}{ B. Single taxpayer with two or more children (by hourly wage level) } \\
\hline$\$ 5.15 / \mathrm{hr}$ & $-25 \%$ & $-25 \%$ & $-25 \%$ & $15 \%$ & $15 \%$ & $15 \%$ \\
\hline$\$ 7.50 / \mathrm{hr}$ & $-25 \%$ & $-13 \%$ & $-2 \%$ & $15 \%$ & $12 \%$ & $12 \%$ \\
\hline$\$ 10 / \mathrm{hr}$ & $-25 \%$ & $-3 \%$ & $18 \%$ & $15 \%$ & $10 \%$ & $10 \%$ \\
\hline$\$ 12 / \mathrm{hr}$ & $-21 \%$ & $3 \%$ & $26 \%$ & $14 \%$ & $11 \%$ & $11 \%$ \\
\hline$\$ 15 / \mathrm{hr}$ & $-13 \%$ & $12 \%$ & $38 \%$ & $12 \%$ & $14 \%$ & $14 \%$ \\
\hline
\end{tabular}

Note: Calculated using TAXSIM. Numbers represent the average tax rate associated with increasing labor supply (either from no work to work or from part time to full time work). Taxes include all federal income taxes plus the payroll tax (assuming individual bears entire 15.3\% rate). Part time work is assumed to be 20 per week and 52 weeks per year and full time work is assumed to be 40 hours per week, 52 weeks per year. 
Table VII

Average Tax Rates for Hypothetical Married Women with Children (2004 tax law)

Taxes Calculated with and without the EITC

\begin{tabular}{rrrrrrr}
\hline \hline \multicolumn{2}{c}{ Average Tax Rates with the EITC } & \multicolumn{2}{c}{ Average Tax Rates without the EITC } \\
\cline { 3 - 6 } No work to & No work to & PT to & No work to & No work to & PT to \\
PT work & FT work & FT work & PT work & FT work & FT work \\
\hline
\end{tabular}

A. Married women with one child (by hourly wage)

$\begin{array}{lrrrrrr}\$ 5.15 / \mathrm{hr} & 8 \% & 18 \% & 27 \% & 5 \% & 8 \% & 11 \% \\ \$ 7.50 / \mathrm{hr} & 30 \% & 36 \% & 41 \% & 14 \% & 20 \% & 25 \% \\ \$ 10 / \mathrm{hr} & 41 \% & 35 \% & 30 \% & 25 \% & 27 \% & 29 \% \\ \$ 12 / \mathrm{hr} & 35 \% & 33 \% & 30 \% & 27 \% & 29 \% & 30 \% \\ \$ 15 / \mathrm{hr} & 30 \% & 30 \% & 30 \% & 30 \% & 30 \% & 30 \%\end{array}$

B. Married women with two or more children (by hourly wage)

\begin{tabular}{lrrrrrr}
$\$ 5.15 / \mathrm{hr}$ & $9 \%$ & $18 \%$ & $26 \%$ & $5 \%$ & $5 \%$ & $5 \%$ \\
$\$ 7.50 / \mathrm{hr}$ & $26 \%$ & $32 \%$ & $39 \%$ & $5 \%$ & $11 \%$ & $18 \%$ \\
$\$ 10 / \mathrm{hr}$ & $36 \%$ & $36 \%$ & $36 \%$ & $14 \%$ & $21 \%$ & $28 \%$ \\
$\$ 12 / \mathrm{hr}$ & $41 \%$ & $36 \%$ & $30 \%$ & $23 \%$ & $27 \%$ & $30 \%$ \\
$\$ 15 / \mathrm{hr}$ & $34 \%$ & $32 \%$ & $30 \%$ & $29 \%$ & $29 \%$ & $30 \%$ \\
\hline \hline
\end{tabular}

Note: Calculated using TAXSIM. Numbers represent the average tax rate associated with increasing labor supply (either from no work to work or from part time to full time work). For each calculation, the husband is assumed to be working full-time and full-year at the same hourly wage as the wife. Taxes include all federal income taxes plus the payroll tax (assuming individual bears entire 15.3\% rate). Part time work is assumed to be 20 per week and 52 weeks per year and full time work is assumed to be 40 hours per week, 52 weeks per year. 